\title{
The earliest Pleistocene interglacials in Lithuania in the context of global environmental change
}

\author{
Valentinas BALTRŪNAS ${ }^{1, ~ *}$, Rimantè ZINKUTË ${ }^{1}$, Vaida ŠEIRIENE ${ }^{1}$, Bronislavas KARMAZA ${ }^{1}$, \\ Valentas KATINAS ${ }^{1}$, Dalia KISIELIENE ${ }^{1}$, Rimute STAKĖNIENE ${ }^{1}$ and Violeta PUKELYTÉ ${ }^{1}$ \\ 1 Institute of Geology and Geography, Nature Research Centre, T. Ševčenkos 13, 03-223, Vilnius, Lithuania
}

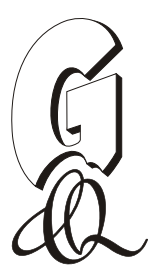

\begin{abstract}
Baltrūnas V., Zinkutè R., Šeirienè V., Karmaza B., Katinas V., Kisielienė D., Stakènienè R. and Pukelytė V. (2014) The earliest Pleistocene interglacials in Lithuania in the context of global environmental change. Geological Quarterly, 58 (1): 145-162, doi: $10.7306 / \mathrm{gq} .1148$

Investigations have been carried out in order to reconstruct the palaeoenvironmental changes during the earliest Pleistocene interglacials and to establish their relation to global environmental changes. Three sections in east Lithuania exposing the earliest Pleistocene lacustrine deposits lying between the Kalviai (Glacial B, Nidanian?) and Dzūkija (Sanian 1) and between Dzūkija (Sanian 1) and Dainava (Sanian 2) glacial deposits were selected for study. Until now the Šlavè-2 and Vindžiūnai-136 successions were considered to have formed during the Vindžiūnai (Augustovian?, Malopolanian) Interglacial and the Kudrè-915 succession during the Turgeliai (Cromerian IV. Ferdynandovian) Interglacial. Geochemical, palaeomagnetic, magnetic susceptibility, anisotropy of magnetic susceptibility and palaeobotanical proxies were applied to establish the cyclicity and dynamics of palaeoenvironmental change. The data obtained enable the subdivision of the section into units related to changes in the sedimentary environment. The Matuyama/Brunhes boundary and Jaramillo subchron of the Matuyama chron have been recognized in the Šlave section. The results enable correction of the stratigraphic position of the sections studied. The sedimentation in the Šlave section took place during the Early Pleistocene, while that at the Vindžiūnai-136 and Kudrè-915 took place during two different Middle Pleistocene interglacials.
\end{abstract}

Key words: environmental changes, geochemistry, magnetic susceptibility, palaeobotany, Early-Middle Pleistocene, Lithuania.

\section{INTRODUCTION}

Inter-regional correlation and global assessment of recent data on Quaternary successions (Cohen and Gibbard, 2011) have helped to revise the stratigraphic schemes in Lithuania (Satkūnas et al., 2007; Guobytė and Satkūnas, 2011). Revision was possible on the basis of new palaeomagnetic data, as the Matuyama/Brunhes (M/B) palaeomagnetic inversion, dated $0.78 \mathrm{mln}$ years BP, was located in sandy deposits of the lower part of Daumantai outcrop (Baltrūnas et al., 2013a). Until now, these deposits have been considered as the oldest Quaternary strata in the region (Daumantai Preglacial of Prepleistocene division). However, the determination of the M/B boundary shows that Early Pleistocene strata are present in the Daumantai sections below this palaeomagnetic boundary. This suggests correlation of the Daumantai sections with sections formed at the beginning of the Middle Pleistocene (Kondratienè, 1996; Satkūnas et al., 2007).

\footnotetext{
*Corresponding author, e-mail: baltrunas@geo.It
}

Received: July 16, 2013; accepted: December 14, 2013; first published online: February 14, 2014
The aim of this research was to reconstruct the palaeoenvironmental changes in east Lithuania during the earliest Pleistocene interglacials and to establish their relation to contemporaneous global environmental change. Three sections representing the earliest Pleistocene integlacials located in eastern Lithuania were studied. Palaeobotanical and palaeomagnetic studies were used to correlate the sections, while geochemical data (major and trace elements, total organic carbon and total inorganic carbon) were aimed at reconstruction of the sedimentary environment, i.e. the combination of physical, chemical and biological processes associated with sedimentation.

Previous investigations suggested that the Šlavè-2 outcrop and the Vindžiūnai-136 borehole sections represent the Vindžiūnai Interglacial, while the Kudrè-915 borehole section represent the Turgeliai Interglacial (Fig. 1).

The Vindžiūnai Interglacial was followed by the first Kalviai (MIS 16) Glacial which covered only the eastern part of Lithuania (Gaigalas, 1987, 2008; Kondratienè, 1996; Guobytè and Satkūnas, 2011). The Vindžiūnai Interglacial has commonly been correlated with the Židini (Latvia), Augustovian (Poland), and Bavelian (Central Europe) interglacials (Gaigalas, 1995, 2008; Kondratienè, 1996; Ber, 2000, 2006; Ber et al., 2007). The deposits of the second interglacial, the Turgeliai (Voigstedt in Germany, Ferdynandovian in Poland, Byelovezha in Belarus) were distinguished in Lithuania in 1961. They lie between tills 


\begin{tabular}{|c|c|c|c|c|c|}
\hline $\begin{array}{l}\text { Palaeomag- } \\
\text { netic chron }\end{array}$ & $\begin{array}{l}\text { Divi- } \\
\text { sion }\end{array}$ & $\begin{array}{l}\text { Subdi- } \\
\text { vision }\end{array}$ & Poland & Lithuania & MIS \\
\hline \multirow{7}{*}{ Bruhnes } & \multirow{9}{*}{ 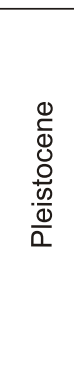 } & \multirow{7}{*}{ Middle } & Mazovian & Butėnai & 11 \\
\hline & & & Sanian 2 & Dainava & 12 \\
\hline & & & Ferdynandovian & Turgeliai & 13 \\
\hline & & & Sanian 1 & Dzūkija & 14 \\
\hline & & & $\begin{array}{l}\text { Kozi Grzbiet } \\
\text { (Domuraty) }\end{array}$ & $\begin{array}{l}\text { Vindžiūnai } \\
\text { (Kemėnai) }\end{array}$ & 15 \\
\hline & & & Nidanian & Kalviai & 16 \\
\hline & & & & Daumantai & $17-21$ \\
\hline \multirow[t]{2}{*}{ Matuyama } & & \multirow[t]{2}{*}{ Early } & $\begin{array}{l}\text { Augustovian } \\
\text { Narevian }\end{array}$ & $?$ & $22-24$ \\
\hline & & & & Šlavè & $25-30$ \\
\hline
\end{tabular}

Fig. 1. Stratigraphic correlation scheme for the Quaternary of Lithuania

formed during the Dzūkija (Elster 1) and Dainava (Elster 2) glacials; furthermore, the tills of both glacials are interstratified with interstadial deposits (Kondratienè, 1996; Baltrūnas, 2002; Ber, 2006; Gaigalas, 2008; Baltrūnas et al., 2008; Guobytè and Satkūnas, 2011).

\section{STUDY SITES}

All study sections are located in the eastern Lithuania, Anykščiai and Vilnius regions - the key areas for Early and Middle Pleistocene deposits (Fig. 2). The Šlavè-2 outcrop is located in the Anykščiai region, $3 \mathrm{~km}$ south-west of Anykščiai $\left(25^{\circ} 04^{\prime} \mathrm{E} / 55^{\circ} 29^{\prime}\right)$, on the right bank of the Šlavè River. The Vindžiūnai-136 borehole is located $35 \mathrm{~km}$ south-east of Vilnius

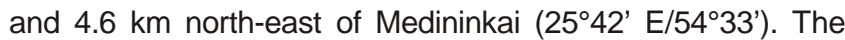
Kudrè-915 borehole is located $9 \mathrm{~km}$ west of Utena and $2 \mathrm{~km}$ north of Pakalniai $\left(25^{\circ} 42^{\prime} \mathrm{E} / 55^{\circ} 26^{\prime}\right)$.

All of these sections are located on palaeodivides of the sub-Quaternary surface near palaeoincisions (Šliaupa, 2004) (Fig. 3). The interglacial lacustrine deposits penetrated by the Vindžiūnai-136 and Kudrè-915 boreholes lie in depressions on the Kalviai and Dzūkija glacigenic deposits respectively. The lithologies and relations of the three sections studied are given in Figure 4.

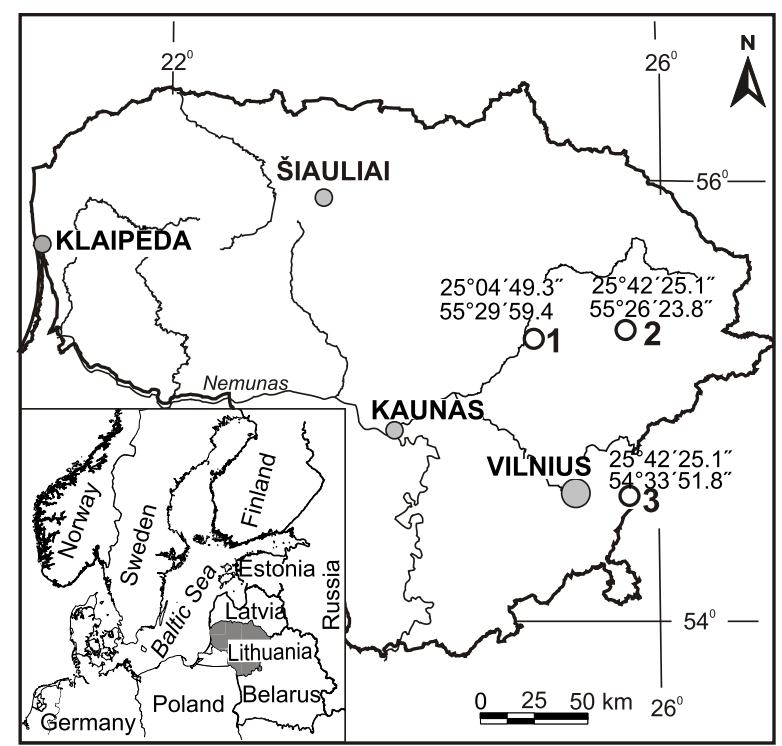

Fig. 2. Location of the sections investigated

\section{METHODS}

Pollen analysis. Chemical preparation followed the standard procedure described by Erdtman (1936) and Grichiuk (1940). To calculate the percentage pollen values, the sum of arboreal $(\Sigma A P)$ and non-arboreal $(\Sigma \mathrm{NAP})$ taxa $(\Sigma \mathrm{AP}+\Sigma \mathrm{NAP}=\Sigma \mathrm{P})$ was used.

Plant macrofossil analysis. Plant macroremains were extracted from the sediment samples (7-10 $\mathrm{dm}^{3}$ in volume) by wet sieving (screens with mesh sizes of 0.2 and $0.5 \mathrm{~mm}$ ) and were analysed using a Nicon SMZ 1500 microscope, at magnifications of 20-60x. The macroremains were identified using the atlases of Berggren (1969, 1981), Grigas (1986), Cappers et al. (2006) and a reference col-

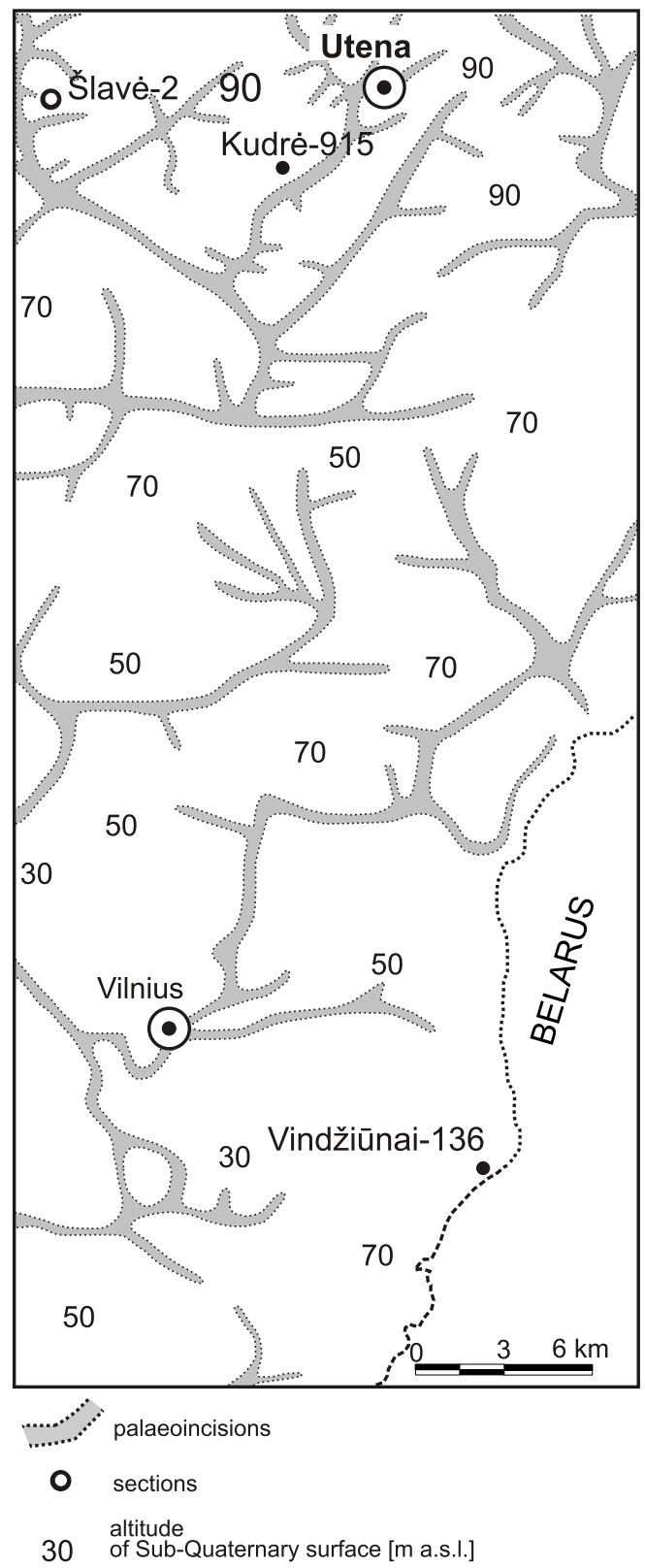

Fig. 3. Sub-Quaternary surface of East Lithuania (according to Šliaupa, 2004) 


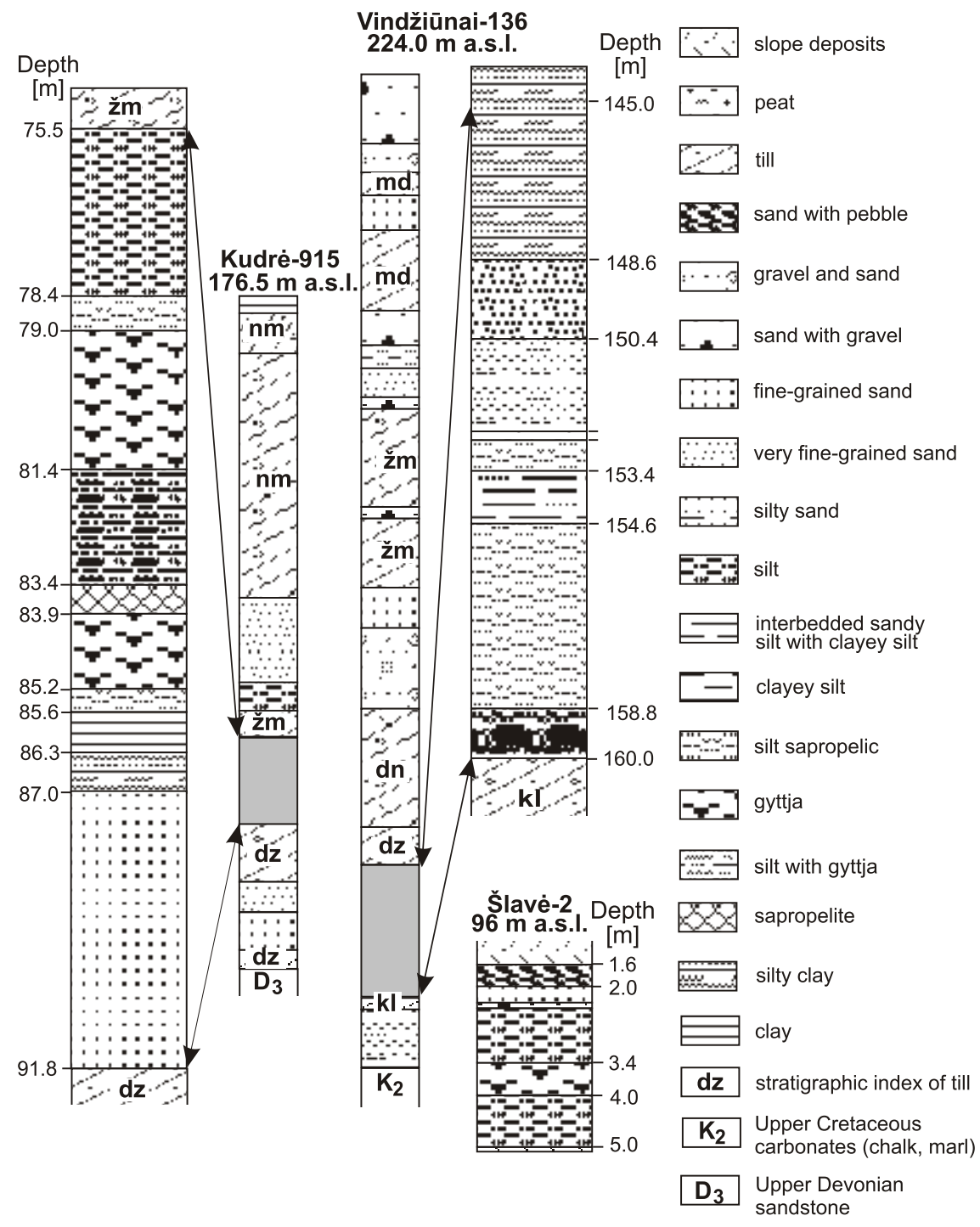

Fig. 4. Lithology and correlation of the sections investigated

Stratigraphic index of tills: dn - Dainava, dz - Dzūkija, kl - Kalviai, md - Medininkai, nm - Nemunas žm - Žemaitija

lection at NRC IGG, Vilnius (Lithuania). Botanical nomenclature follows Gudžinskas (1999).

Diatom analysis. Diatom frustules were extracted from the sediments in the conventional manner as described by Battarbee (1986) and Miller and Florin (1989). HCl was added to remove the carbonates, and $35 \% \mathrm{H}_{2} \mathrm{O}_{2}$ was used to oxidize the organic material. Decanting and flotation in heavy liquids were used to remove clay particles and mineral material. Afterwards, the diatom frustules were mounted into Naphrax liquid and examined under a light microscope with an oil immersion objective at a magnification of $1000 x$.

Determination of magnetic susceptibility. Mass magnetic susceptibility $\left(\mathrm{m}^{3} / \mathrm{kg}^{-1}\right)$ was measured in GTC IGG by a kappabridge MFK1-B (AGICO). The information received was assessed with SAFYR software.

Determination of the anisotropy of magnetic suspectibility (AMS). AMS was measured with a MFK1-B kappabridge (AGICO) at the Palaeomagnetic Laboratory of the IGG. The AMS measurements were made along fifteen different direc- tions (Jelinek, 1977). Analysis of the AMS data was performed using Anisoft 4.2 software.

Palaeomagnetic investigations. The natural remanent magnetisation of samples was measured using a $J R-6$ spinner magnetometer at the Palaeomagnetic Laboratory of the IGG, Nature Research Centre. Magnetic declination and magnetic inclination were determined and plotted for each sample. All samples were subjected to stepwise alternating field (AF) demagnetisation with an $A F M o l s p i n$ demagnetizer. Characteristic directions were calculated using principal component analysis (Kirschvink, 1980).

Determination of total contents of major and trace elements. Samples were air-dried and homogenized. They were then milled for 10 minutes (27 Hz frequency) using a MM 400 mixer mill (Retsch) with grinding jars and grinding balls covered by zirconium oxide. The milled material was homogenized with Licowax (4 $\mathrm{g}$ of sample and $0.9 \mathrm{~g}$ of wax) and pressed with a PP15 press into a $32 \mathrm{~mm}$ pressed pellet. The contents of 10 major elements ( $\mathrm{Si}, \mathrm{Al}, \mathrm{Ca}, \mathrm{Mg}, \mathrm{Fe}, \mathrm{K}, \mathrm{Na}, \mathrm{S}, \mathrm{Ti}, \mathrm{P}$ ) and 19 trace 
elements (As, Ba, Br, Cr, Cu, Ga, Hf, Mn, Mo, Nb, Ni, Pb, Rb, $\mathrm{Sr}$, Th, V, Y, Zn, Zr) were determined by energy-dispersive $X$-ray fluorescence (EDXRF) using Spectro XEPOS equipment and the TURBOQUANT calibration method for pressed pellets. Quality control was assured by participation of the laboratory in the "International Soil-analytical Exchange" (ISE) program of Wageningen Evaluating Programs for Analytical Laboratories (WEPAL).

Determination of total organic carbon (TOC) and total inorganic carbon (TIC). Samples were air-dried, homogenized and milled using a MM 400 mixer mill as described above. Direct determination of total carbon (TC) was done by the high-temperature oxidation method using a liquiTOC elemental analyser (Elementar analysensysteme $\mathrm{GmbH}$, Hanau-Germany). The procedure involved heating the sample at $950^{\circ} \mathrm{C}$ and measuring the combustion products by infrared energy detector with a precision of $\pm 1 \%$ (Leong and Tanner, 1999). The carbonate-free residue was washed with deionized water, dried, and then the TOC content was measured. The difference between the two carbon measurements (TIC-TOC) gives the total inorganic carbon (TIC) content.

Calculation of organic matter (OM) from TOC was achieved by using a conversion factor of 2.8 , which resembles the Redfield ratio. The percentage of total carbonates (TCR) is calculated by dividing the percentage of carbonate carbon (TIC) by 0.12 , the fraction of carbon in $\mathrm{CaCO}_{3}$. This conversion probably slightly overestimates the total carbonate content, because most samples contain minor amounts of dolomite that contains 13 wt.\% of carbon (Dean and Schwalb, 2000). The amount of inorganic, non-carbonate minerals (NCM) was calculated as the difference between $100 \%$ and the sum of the percentages of organic matter and total carbonates. The value is often referred to as the "detrital-clastic" fraction, although in the sediments of many lakes this fraction also includes siliceous diatom remains (Dean and Schwalb, 2000).

Statistical treatment of geochemical data. Statistical treatment of data was based on the findings of Engstrom and Wright (1984) that the allogenic, authigenic and biogenic components of lake sediments can be distinguished. Allogenic material is mainly minerogenic, largely crystalline and allochthonous; authigenic matter is allochthonous in origin but fixed as sediment by chemical and physical processes in the water column (chemical precipitation and flocculation, adsorption onto colloidal particles), while biogenic material has passed through the food chain either in the lake ecosystem or in the catchment (Heathwaite and O'Sullivan, 1991; Boyle, 2001; O'Sullivan and Reynolds, 2003). Classification of lake sediments is also often based on three analogous components: clastic, chemical and biological (Garunkštis, 1975; Schnurrenberger et al., 2003). These findings enabled the following:

1 - the main three components of lake sediments can be distinguished according to major and trace elements using multivariate methods;

2 - interpretation of the distinguished latent components can be substantiated by analysing their correlation with TOC and TIC and comparing with the results of other researchers;

3 - the relative importance of these components in three sections can be used for their comparison, and for subdivision of the sections into sedimentary units.

Factor analysis (principle component analysis with varimax rotation) was chosen as a suitable multivariate statistical method for the following reasons:

1 - it can be applied even to heterogeneous data sets for establishment of the principal differences between sub-sets (Iberla, 1980);
2 - it has been applied earlier not only to lithologically homogeneous sections (Baltrūnas et al., 2013a) but also to heterogeneous sections, composed of different lithologies (Baltrūnas et al., 2013b).

\section{RESULTS OF INVESTIGATIONS}

\section{PALAEOBOTANICAL INVESTIGATIONS}

All three sections were investigated for pollen, plant macroremains and diatoms.

Pollen grains obtained in Šlavè-2 outcrop are well-preserved. The richest pollen flora was found in the middle part of the section in silt and gyttja layers, and is characteristic of the interglacial (Kondratienè and Riškienè, 1971; Kondratienè, 1996). In the lowermost part, during the late glacial and the beginning of the interglacial, Betula prevails among trees comprising $80-95 \%$ of total flora (Fig. 5). Towards the upper part of the section Alnus and Pinus appear. The first broad-leaved trees appear at the bottom of a gyttja layer and Quercus dominates among them, comprising up to $15 \%$ as the other broad-leaved trees are found in small numbers. Picea appears contemporaneously with deciduous trees as well as with some exotic species: Ilex, Celtis, Vitis, Osmunda, Azolla (Kondratienè, 1996). In the lowermost and uppermost parts of the section, considerable numbers of herbs are present.

The richest macrofossil flora was obtained from the deposits of the middle part of the section at a depth of 3.2-4.2 m (Table 1). Herbs dominate (NAP $85 \%$ ) and most of these represent aqueous or wet habitats. This indicates that sedimentation took place in a lake. Remains of recent as well as of extinct plants are numerous. Extinct species compose a third of the total flora [Pilularia pliocenica Dorof., Eleocharis ex gr. pseudoovata Dorof., Alisma plantago-minimum (Nikit.) Dorof. ex Wieliczk. and others]; among them, Pliocene species dominate. Most of these species were identified as confer (=cf) (Sparganium cf. emersum Rehm., Potamogeton cf. obtusifolius Mert. et W.D.J. Koch, $P$. cf. rutilus Wolfg., Lemna cf. trisulca L. and others) as they show morphological features characteristic of older co-generic species. No tree macroremains were identified.

\section{DIATOMS WERE ABSENT STRATA SAMPLED AT OUTCROP}

Pollen identified at a depth of 153.8-159.8 $\mathrm{m}$ in the Vindžiūnai-136 section is of interglacial character (Fig. 6). The pollen spectra indicate Pinus-Betula forests with open areas. The thermal optimum of the interglacial was recorded at a depth of 154.6-158 m and its first part was more continental than the second. Mixed forests prevailed. Quercus dominated among broad-leaved trees (up to 14\%), while pollen of Larix, Rhododendron, Ephedra was present indicating possible open areas. Some species of Neogene flora (Pterocarya, Ostrya, Tsuga) were found. Records of the water-living species Nymphaea, Trapa and Azolla point to a mild climate. Pollen flora from the depth interval 153.8-154.6 m indicates more severe climatic conditions as only a few grains of broad-leaved pollen and thermophilous species were found.

Plant macrofossils were present at a depth of 157-159.8 m. Sixteen species were identified. A considerable part of the flora comprised extinct species (44\%), such as Azolla interglacialica Nikit., Potamogeton trichoides Cham. et Schlecht., P. perforatus Wieliczk., $P$. cf. parvulus Dorof., Eleocharis 


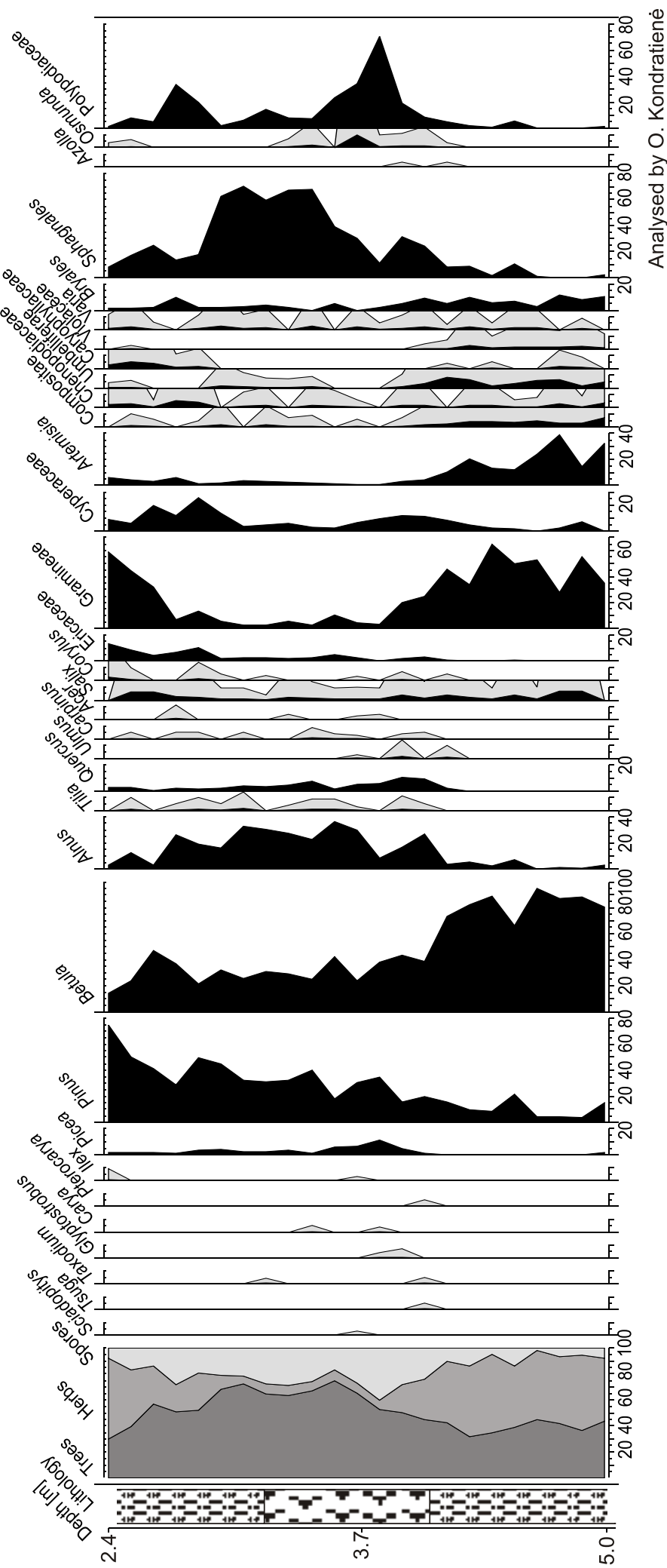

Fig. 5. Pollen diagram of the Šlavè-2 section (by Kondratiené, 1996)

For lithology explanations see Figure 4 praemaximowiczii Dorof., Ranunculus sceleratoides Nikit. and Elatine hydropiperoides Dorof. ex Wieliczk. The species Potamogeton trichoides is characteristic of a warm climate and is common in interglacial deposits only at their optimum (Velichkevich et al., 1998). Because of the fragmentary character of the complex, no tree macrofossils were obtained, except for one record of Larix sp.

The deposits are poor in diatoms and the richest diatom flora was obtained in the interval 150.4-156.8 m. The planktonic diatom species Aulacoseira granulata, A. islandica and Stephanodiscus rotula dominate, indicating sedimentation in a eutrophic lake. Some extinct species are also present.

Pollen spectra of the Kudrè-915 section (at the depth interval of 76.5-91.8 m) indicate the thermal optimum of the interglacial at 83.8-85.8 $\mathrm{m}$ (Kondratienè, 1996). Betula and Betula-Pinus forests existed at the beginning, which were later replaced by coniferous-deciduous forests with Corylus. The first broad-leaved taxa which appeared were Quercus, Ulmus, Tilia, and later Carpinus and Acer. During the second half of the thermal optimum, expansion of Picea started, as the climatic conditions probably became cooler. The end of the interglacial could be characterized as representing a severe climate, because of the existence of such species as Betula nana L., Alnaster, and Lycopodium appressum (Desv.) Petr. Pliocene relicts Pinus cembra, P. strobus, Picea sect. omorica, Tsuga, Pterocarya, Vitis, Ilex, Azolla and Osmunda are present as well. This interglacial was characterized by an absence of differentiation of vegetation during the climatic optimum and a high frequency of trees and shrubs (up to 40\%) including Artemisia and Chenopodiaceae (Kondratiené, 1996).

The Kudrè-915 succession representing the beginning of the interglacial and the thermal optimum is poor in diatoms. Only single frustules of Aulacoseira granulata, Ellerbeckia arenaria, Opephora martyi, Gyrosigma attenuatum, and Cymbella ehrenbergii were found (Fig. 7, zone I). The second half of the interglacial $(77-83.7 \mathrm{~m})$ is very rich in diatoms (Fig. 7, zones II-VI), that are dominated by periphytic freshwater taxa. At the depth interval 83.6-82.4 m the number of diatoms increases. Epiphytic and benthic species dominate (up to $75 \%$ of the total flora): e.g., Ellerbeckia arenaria, Gyrosigma attenuatum, Opephora martyi, Fragilaria construens and Cymbella ehrenbergii. The planktonic taxon Aulacoseira granulata accounts for $20 \%$. At 81.8-78.4 $\mathrm{m}$ a very rich diatom flora was obtained, dominated by epiphytic and benthic species (up to 50-90\%), e.g., Opephora martyi, Fragilaria brevistriata, Gyrosigma attenuatum and Cymbella ehrenbergii. Among planktonic taxa Aulacoseira granulata, $A$. islandica morph. helvetica and $A$. ambigua are the most common. In the uppermost part of the section $(78.4-77.0 \mathrm{~m})$ the number of planktonic species decreases. Periphytic species are predominated by representatives of the genus Fragilaria and benthic species by Pinnularia viridis, Gyrosigma attenuatum, Amphora ovalis and Cymbella ehrenbergii. The aerophilous diatoms Pinnularia borealis and Hantzchia amphioxys are present.

The diatom flora investigated at Kudrè-915 indicates that sedimentation took place in the littoral zone of a eutrophic lake. From the lower to the upper part of the section, the water level gradually decreased. 
Plant macrofossils from the Šlavè-2 outcrop section

\begin{tabular}{|c|c|c|c|c|c|c|c|c|c|c|c|c|c|c|}
\hline \multirow[b]{2}{*}{ Species name } & \multicolumn{14}{|c|}{ Depth [m] } \\
\hline & $\begin{array}{l}\stackrel{O}{0} \\
\dot{+} \\
\stackrel{m}{+} \\
\dot{\forall}\end{array}$ & $\begin{array}{l}m \\
\stackrel{+}{+} \\
\qquad \\
\circ \\
\dot{\forall}\end{array}$ & 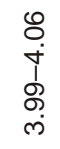 & 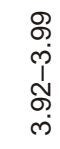 & $\begin{array}{l}\text { N } \\
\text { ल) } \\
1 \\
\infty \\
\infty \\
\dot{m}\end{array}$ & $\begin{array}{l}\infty \\
\infty \\
\infty \\
\rho \\
\infty \\
\infty \\
\rho \\
\dot{\rho}\end{array}$ & $\begin{array}{l}\infty \\
\stackrel{\infty}{p} \\
\dot{p} \\
\frac{1}{N} \\
\dot{m}\end{array}$ & $\begin{array}{l}\bar{N} \\
\dot{p} \\
\dot{1} \\
\dot{0} \\
\dot{m}\end{array}$ & \begin{tabular}{l}
\multirow{0}{0}{} \\
$\dot{p}$ \\
1 \\
10 \\
$\dot{n}$ \\
$\dot{m}$
\end{tabular} & $\begin{array}{l}\hat{N} \\
\tilde{N} \\
\tilde{1} \\
\tilde{N} \\
\tilde{N} \\
\tilde{\infty}\end{array}$ & 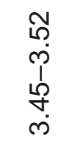 & 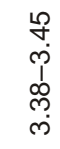 & $\begin{array}{l}\infty \\
m \\
m \\
p \\
p \\
\rho \\
\dot{m}\end{array}$ & 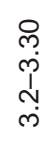 \\
\hline Chara sp. & & & & & 1 & 3 & 1 & & & & & & & \\
\hline Selaginella selaginoides (L.) Link & 3 & 11 & 35 & 28 & 58 & 41 & 63 & 22 & 14 & 5 & 8 & 21 & 18 & 2 \\
\hline Selaginella sp. & 3 & & & 1 & 2 & 8 & 13 & & 1 & & & & & 1 \\
\hline Salvinia aphtosa Wieliczk. & & 2 & 5 & 4 & 15 & 19 & 20 & 13 & 24 & 34 & 12 & 18 & 2 & \\
\hline Salvinia tetraedra Wieliczk. & & & 1 & & 2 & 1 & & 2 & 15 & 6 & 3 & 9 & 4 & \\
\hline Salvinia sp. & 1 & & 2 & & 1 & 3 & 1 & 1 & & 4 & 1 & & & \\
\hline Azolla interglacialica Nikit. & & & 1 & 52 & 67 & & & & 18 & 5 & 3 & & & \\
\hline Pilularia pliocenica Dorof. & & & & 1 & 2 & & & & & & & & & \\
\hline Sparganium minimum Wallr. & & 1 & 3 & & 2 & & 1 & 1 & & & & & & \\
\hline Sparganium cf. emersum Rehm. & & & 12 & 3 & & 6 & & & & & & & & \\
\hline Potamogeton filiformis Pers. & & & & 2 & 1 & 1 & & & & & & & & \\
\hline $\begin{array}{l}\text { Potamogeton cf. obtusifolius Mert. } \\
\text { et W.D.J. Koch }\end{array}$ & & 1 & 1 & 5 & & 7 & 1 & & & & & & & \\
\hline Potamogeton cf. rutilus Wolfg. & & 4 & 1 & 3 & & 2 & & & & & & & & \\
\hline Potamogeton sp. & & & & & 1 & & & & & & & & & \\
\hline Alisma plantago-aguatica L. & 3 & & 3 & 8 & 14 & 2 & & 12 & & & & & & \\
\hline $\begin{array}{l}\text { Alisma plantago-minimum (Nikit.) } \\
\text { Dorof. ex Wieliczk. }\end{array}$ & & 1 & 8 & 2 & 5 & & 1 & & & & & & & \\
\hline Alisma sp. & & 2 & 6 & 18 & 44 & 26 & & 5 & & & & & & \\
\hline Alismataceae gen. & & 1 & & & 1 & 2 & & & & & & & & \\
\hline Sagittaria sagittifolia L. & & & 1 & & & & & & & & & & & \\
\hline Eleocharis palustris (L.) R. Br. & 2 & & 1 & & 8 & & & & & & & & & \\
\hline $\begin{array}{l}\text { Eleocharis ex gr. pseudoovata } \\
\text { Dorof. }\end{array}$ & & & & & & 1 & & & & & & & & \\
\hline Carex paucifloroides Wieliczk. & & 1 & & 13 & 5 & 1 & 19 & & 1 & 1 & & & & \\
\hline Carex sp. & & 2 & 1 & & 17 & 12 & 21 & 15 & & 4 & 2 & & & \\
\hline Lemna cf. trisulca L. & & & 3 & 18 & & 3 & & 2 & & & & & & \\
\hline Ranunculus sceleratoides Nikit. & 2 & 8 & 2 & 1 & 48 & 32 & 26 & 30 & 12 & 3 & & & & \\
\hline Ranunculus sp. & 2 & & & 2 & 6 & & 1 & & & & & & & \\
\hline Lysimachia thyrsiflora (L.) Rchb. & 1 & 2 & 38 & 16 & 28 & 8 & 21 & 4 & 3 & 2 & 2 & 1 & & \\
\hline Urtica dioica L. & & & & & 1 & & 1 & & 2 & 1 & & & & \\
\hline Potentilla sp. & & 1 & & & 1 & & & & & & & & & \\
\hline Myriophyllum verticillatum $\mathrm{L}$. & & & 1 & 4 & 6 & & & 2 & & & & & & \\
\hline Menyanthes thrifoliata L. & & & & & 1 & & 1 & 2 & & & & & & \\
\hline Hippuris vulgaris L. & & 2 & 9 & 18 & 25 & 4 & & 15 & & & & & & \\
\hline
\end{tabular}

\section{PALAEOMAGNETIC INVESTIGATIONS}

Examples of the progressive alternating field (AF) demagnetisation behaviour of the Šlavè-2 section samples are shown on orthogonal plots and equal-area projections in Figure 8. Stepwise AF demagnetisation shows one kind of overprint in the samples from the Šlavè-2 section. All samples contained a low coercivity component that was removed in a field from 40 to $60 \mathrm{mT}$. Demagnetisation results show that all samples in the interval from 2.4 to $3.2 \mathrm{~m}$ have a reversed polarity direction; from $3.2 \mathrm{~m}$ to the lower part of the section they have a mixed magnetic polarity (Figs. 8 and 9 ).

\section{INVESTIGATIONS OF THE ANISOTROPY} OF MAGNETIC SUSCEPTIBILITY

Analysis of the anisotropy of magnetic susceptibility (AMS) has been applied to the rock fabric investigation. AMS measurement of one rock specimen results in an ellipsoid of magnetic susceptibility $(K)$ defined by the length and orientation of its three principal axes, $K_{\max }>K_{\text {int }}>K_{\min }$ which are the eigenvectors of the susceptibility tensor. The long axis of the magnetic susceptibility ellipsoid $K_{\max }$ defines the magnetic lineation; the short axis $K_{\min }$ defines the magnetic foliation. In a standard model, the magnetic lineation coincides with sedi- 

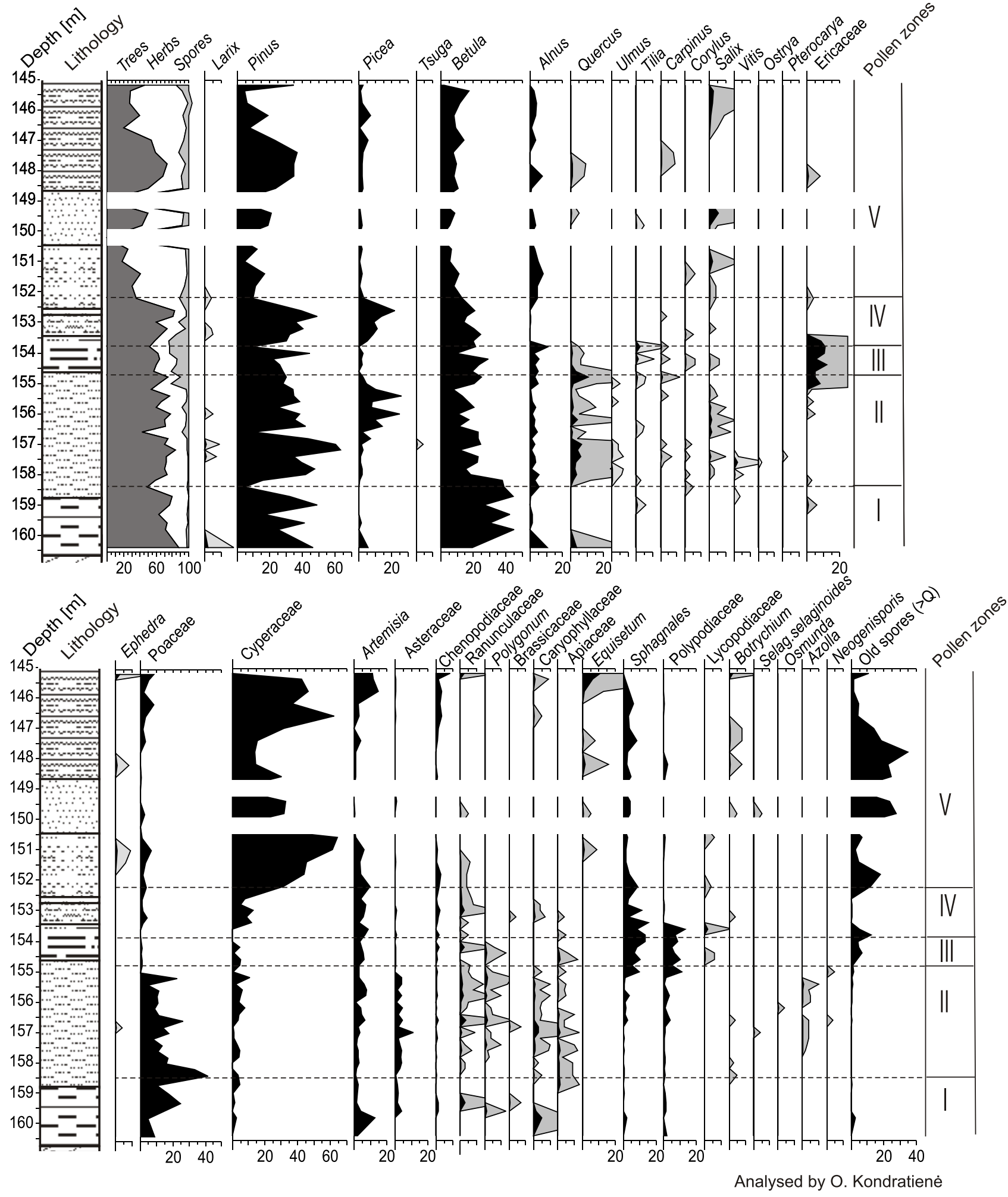

Fig. 6. Pollen diagram of the Vindžiūnai-136 section (by Kondratienè, 1996) 


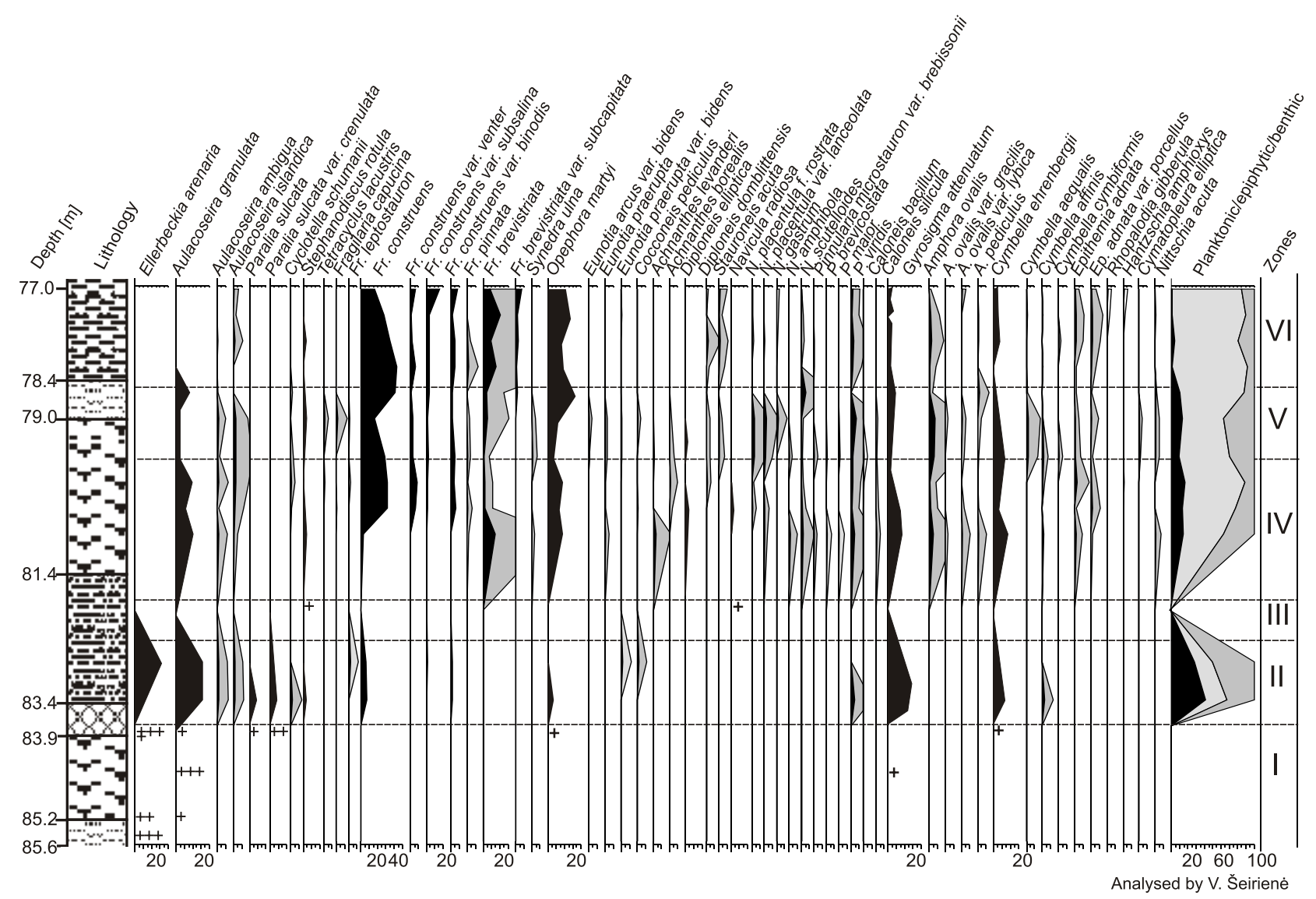

Fig. 7. Diatom diagram of the Kudrè-915 section

For lithology explanations see Figure 4

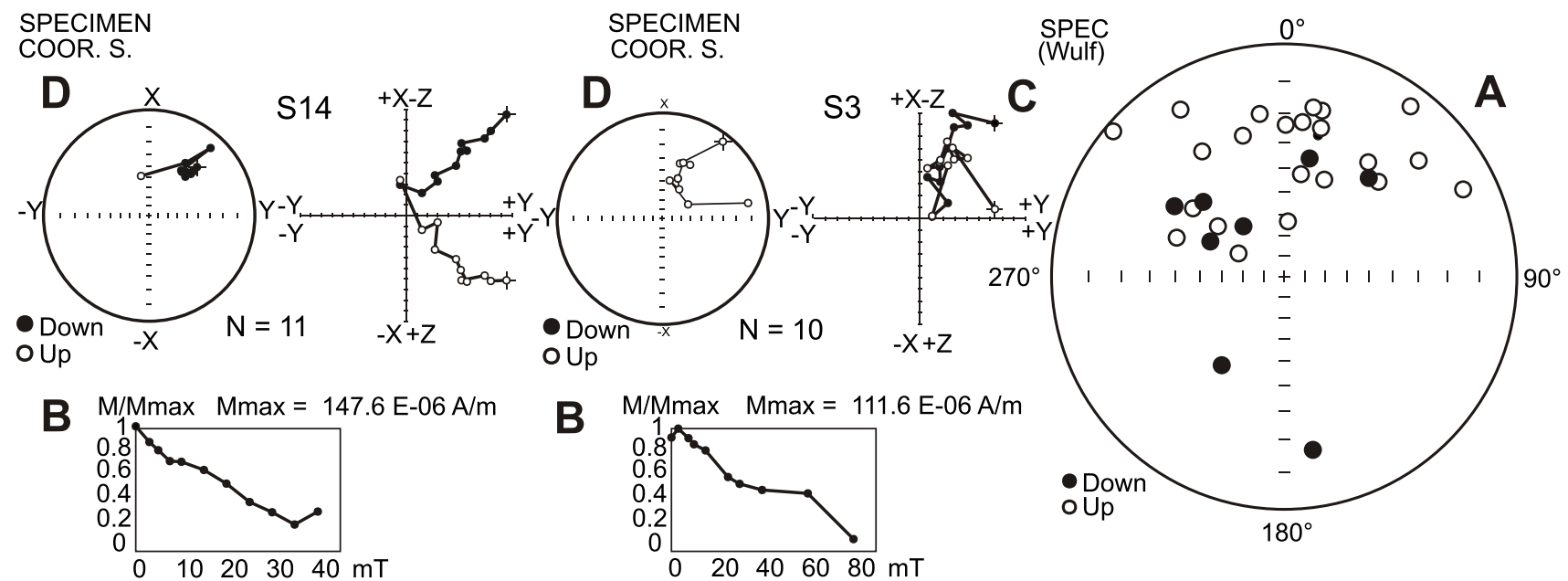

Fig. 8. Representative demagnetization results (B, C, D) of samples S14 and S3 from the Šlave-2 section and (A) ChRM directions

A - characteristic remanent magnetization directions (ChRM); B - changes in intensity of NRM; C - horizontal and vertical projections of the NRM vector combined into a single vector component diagram; $\mathbf{D}$ - equal area projections which display the direction of natural remanent magnetization (NRM) vector; depth location of samples S14 and S3 is indicated in Figure 9; N - number of demagnetization steps, SPECIMEN COORD S.; SPEC - specimen coordinate system, M/Max - ratio of geomagnetic palaeointensity (M) to maximum geomagnetic palaeointensity (Mmax) 


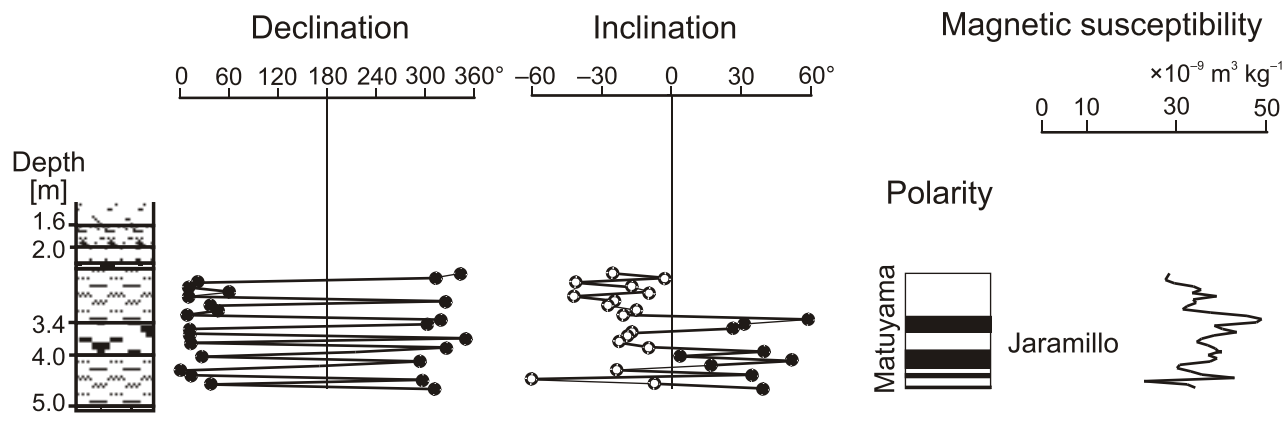

Fig. 9. Magnetic susceptibility, declination, inclination and polarity scale from the Šlavè-2 section

In the inclination plot, the white circles indicate reversed polarity, the black circles normal polarity; for lithology explanations see Figure 4

mentary or volcanic flow directions while the $K_{\min }$ is perpendicular to the surface of the flow (Cañón-Tapia, 2004).

The results of AMS measurement of 24 oriented samples from the Šlavè-2 section (Fig. 10) show that the main azimuth of the direction of the inflow of sedimentary material in the Šlavè-2 section is $86^{\circ}$, i.e. from west to east. The small bank angle indicates a slow rate of inflow of sedimentation (Table 2).

\section{INVESTIGATIONS OF MAGNETIC SUSCEPTIBILITY (MS)}

The Šlavè-2 section is characterized by the lowest range of variation of MS: from 22.4 to $49.1 \times 10^{-9} \mathrm{~m}^{3} \mathrm{~kg}^{-1}$ (Fig. $11 \mathrm{~A}$ ). In the other two sections the MS is higher: in the Vindžiūnai-136 borehole section from 39.1 to $256 \times 10^{-9} \mathrm{~m}^{3} \mathrm{~kg}^{-1}$ (Fig. 12A) and in Kudrè-915 borehole section from 55.4 to $142.9 \times 10^{-9} \mathrm{~m}^{3} \mathrm{~kg}^{-1}$ (Fig. 13A). The median of MS in Šlavè-2 is $34.4 \times 10^{-9} \mathrm{~m}^{3} \mathrm{~kg}^{-1}$; in the Vindžiūnai-136 section it is $77.7 \times 10^{-9} \mathrm{~m}^{3} \mathrm{~kg}^{-1}$ and in the Kudrè-915 section it is $95.5 \times 10^{-9} \mathrm{~m}^{3} \mathrm{~kg}^{-1}$, indicating an increase of MS in younger interglacial deposits. The highest coef- ficient of variation of MS (46.4\%) is in the Vindžiūnai-136 section. In other sections it is lower: $19.2 \%$ in Šlavè-2 and $20.5 \%$ in Kudrè-915.

In the Šlavè-2 section (Fig. 11A), relatively low MS values (below $30 \times 10^{-9} \mathrm{~m}^{3} \mathrm{~kg}^{-1}$ ) are in the depth interval of 2.4-3.2 $\mathrm{m}$ and in one sample at a depth of $4.68 \mathrm{~m}$. Other samples have relatively high MS values. The section can be subdivided into three parts: lower (from 4.8 to $4.5 \mathrm{~m}$ ); middle (from 4.5 to $3.4 \mathrm{~m}$ ) and upper (from 3.4 to $2.4 \mathrm{~m}$ ). The highest peak P6 is in the middle part of the section as well as most of the other peaks P3, P4, P5 and P7. The increasing trend of MS from the depth of $4.5 \mathrm{~m}$ to $\mathrm{P} 6$ and then a decreasing trend from $\mathrm{P} 6$ to $3.4 \mathrm{~m}$ can be observed. A general decrease in MS is registered in the upper part of the section.

In the Vindžiūnai-136 section (Fig. 12A), there are mostly relatively low values of MS (from 39.1 to $90 \times 10^{-9} \mathrm{~m}^{3} \mathrm{~kg}^{-1}$ ), by comparison with which 8 intervals with MS increase can be observed: P1, P2, P3, P4, P5, P6, P7 and P8. The highest value is at P1 $\left(256 \times 10^{-9} \mathrm{~m}^{3} \mathrm{~kg}^{-1}\right)$. The lowermost part of the section is characterized by large fluctuations of MS, but peaks P2 and P3 are lower than P1. Upwards from P3 a trend of decreasing MS

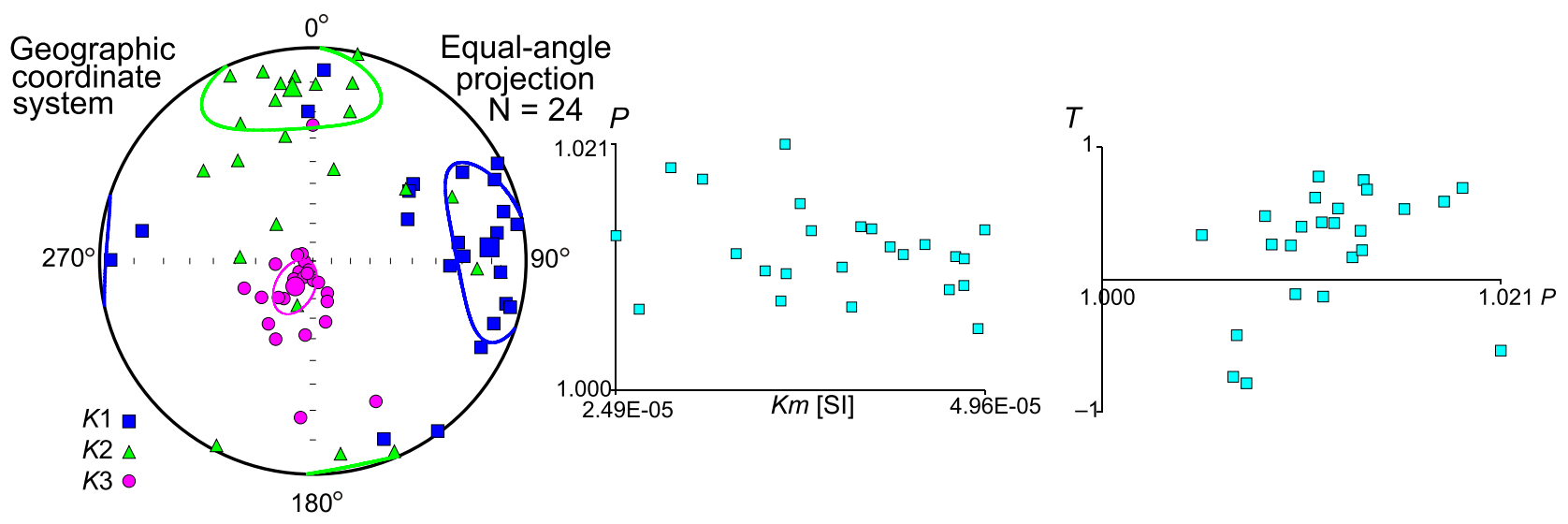

Fig. 10. Anisotropy of magnetic susceptibility directional results of the Šlavè-2 section

Small symbols represent specimen eigenvectors; large symbols represent mean eigenvectors: $K 1=K_{\max }, K 2=\mathrm{K}_{\text {int }}, K 3=K_{\min }$; $P$ - anisotropy degree, $T$ - shape parameter, $K m$ - magnetic susceptibility (10-6SI) 
Table 2

Anisotropy of magnetic susceptibility parameters of the Šlavè-2 section

\begin{tabular}{|c|c|c|c|c|c|c|c|}
\hline$N$ & $K m\left(10^{-6} \mathrm{SI}\right)$ & $L$ & $F$ & $P$ & $T$ & $K_{\max }\left[^{\circ}\right]$ & $K_{\min }\left[^{\circ}\right]$ \\
\hline 24 & $3.96 \mathrm{E}-5$ & 1.003 & 1.007 & 1010 & 0.484 & $86 / 11$ & $215 / 74$ \\
\hline
\end{tabular}

$N$-number of samples, $K m$ - magnetic susceptibility, $L$-magnetic lineation, $F$-magnetic foliation, $P$-anisotropy degree, $T$ - shape parameter, $K_{\max }$ - long axis (declination and inclination), $K_{\min }-$ short axis (declination and inclination)
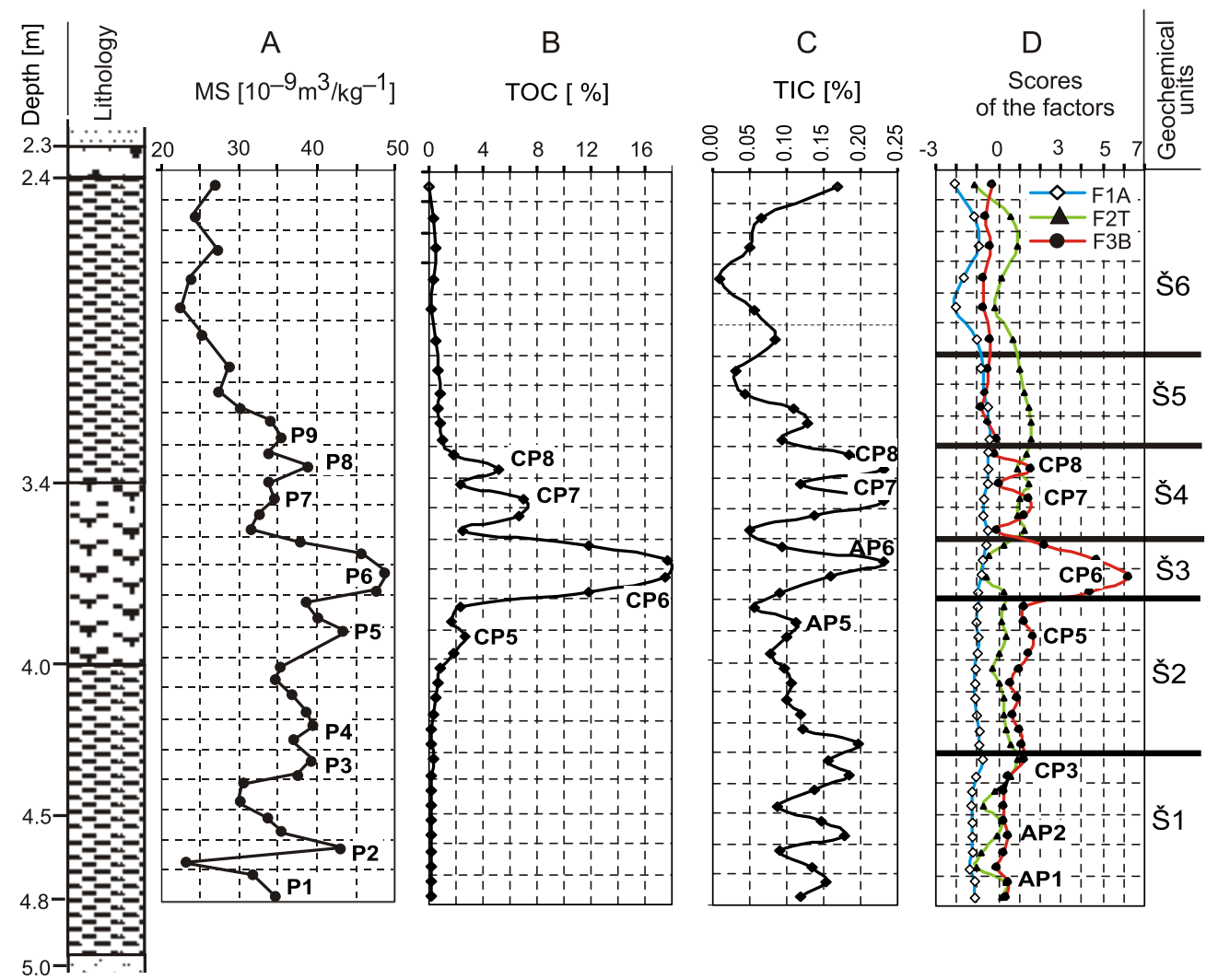

Fig. 11. Summary diagram of the Šlavè-2 outcrop section

The factors: F1A - authigenic, F2M - allogenic (terrigenous, minerogenic), F3B - biogenic; For lithology explanations see Figure 4

can be seen, but it is followed by a sharp increase at P4. Upwards from $\mathrm{P} 4$ again a tendency towards decrease can be observed with smaller amplitude fluctuations and lower peaks P5 and P6. Upwards from the depth of $151 \mathrm{~m} \mathrm{MS}$ increases to the relatively high $\mathrm{P} 7$ peak. Then it again decreases to the depth of $148 \mathrm{~m}$ and upwards from this depth MS grows until it reaches P8 in the uppermost part of the section.

The Kudrè-915 section (Fig. 13A) mostly shows relatively low values of MS (from 55.4 to $100 \times 10^{-9} \mathrm{~m}^{3} \mathrm{~kg}^{-1}$ ). By comparison with these, eleven peaks (P1-P11) can be distinguished. Most of the relatively low values are in the lower part of the section (from 92 to $83.8 \mathrm{~m}$ ) and there are only two peaks in this part. Upwards from P24 until the depth of $84.4 \mathrm{~m}$ a decreasing trend of MS can be observed. From 84.4 to $83.8 \mathrm{~m} \mathrm{MS}$ increases once more. The upper part (from 83.8 to $75.8 \mathrm{~m}$ ) is characterized by large fluctuations in MS and presence of many peaks (P3-P11). The highest MS is observed in the uppermost part of the section in peak $\mathrm{P} 11$, reaching a value of $143 \times$ $10^{-9} \mathrm{~m}^{3} \mathrm{~kg}^{-1}$. The upper part can be subdivided into two intervals: from 83.8 to $78 \mathrm{~m}$ and from 78 to $75.8 \mathrm{~m}$; an increasing trend can be observed in the second interval.

\section{INVESTIGATIONS OF TOC AND TIC}

The range of TOC content in the Vindžiūnai-136 section (0.04-2.31\%; Fig. 12B) is clearly lower than in the Šlavè-2 section (0.08-17.7\%; Fig. 11B) and in the Kudrè-915 section (0.11-18.1\%; Fig. 13B). The lowest median content of TOC $(0.25 \%)$ is in the Vindžiūnai-136 section; it is higher $(0.62 \%)$ in the Šlavè-2 section and highest (3.89\%) in the Kudrè-915 section. 


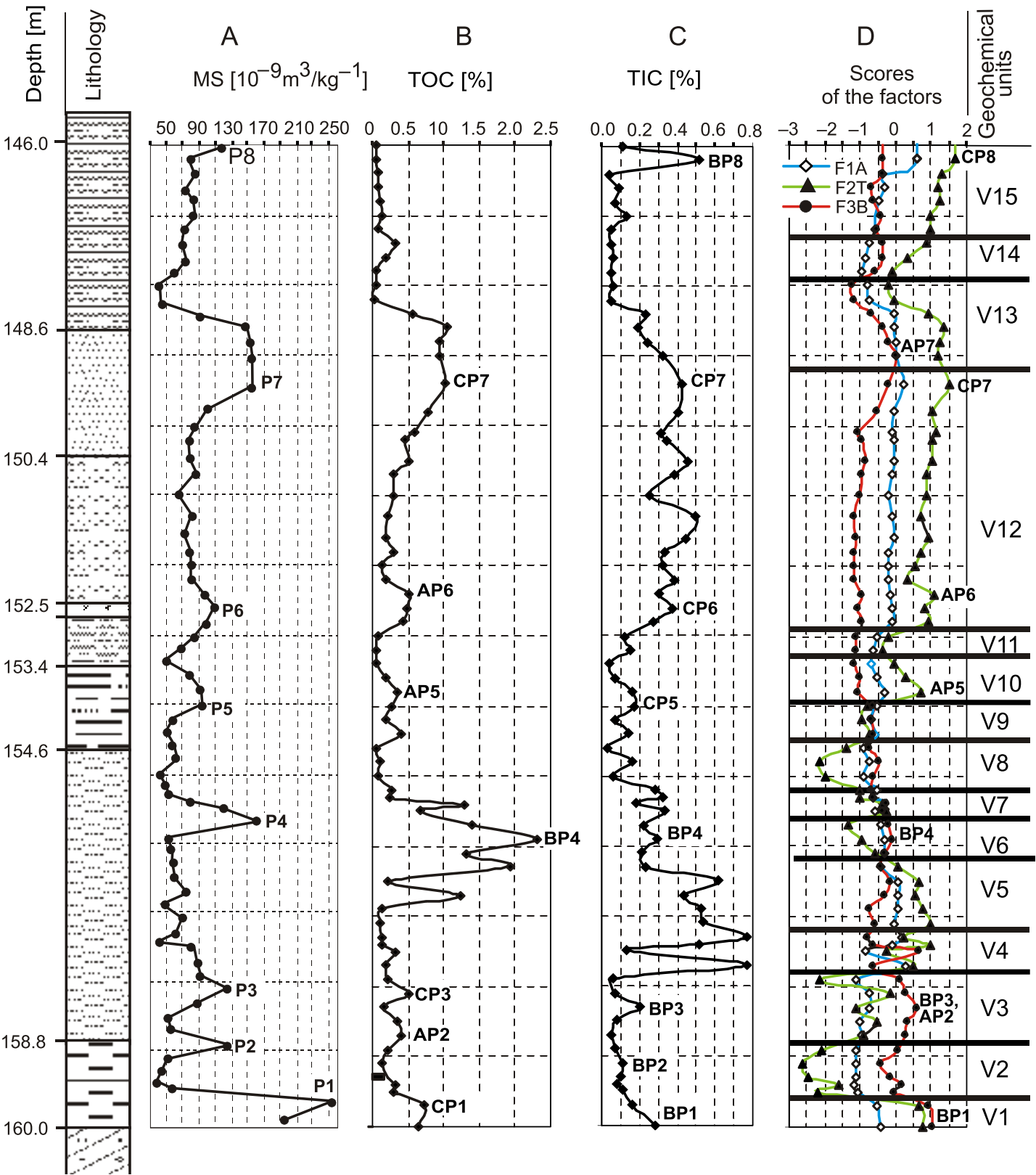

Fig. 12. Summary diagram of the Vindžiūnai-136 borehole section

For explanations see Figures 4 and 11

The lowest range of TIC content is in the Šlavè-2 section (0.01-0.23\%; Fig. 11C); it is followed by the Vindžiūnai-136 section (0.03-0.77\%; Fig. 12C) and is highest in the Kudrè-915 section (0.92-5.67\%; Fig. 13C). The sections are also arranged in the same order as regards the median content of TIC: $0.11 \%$ in Šlavè-2, $0.20 \%$ in Vindžiūnai-136 and $2.64 \%$ in Kudrè- 915 . The median TIC concentration in the Kudrè-915 section is 24 times as high as in the Šlavè-2 section. This indicates that the Kudrè-915 deposits are rich both in organic material and in inorganic carbon (calcium carbonates).

The variation coefficients (VK) of TOC in all sections are higher than those of TIC. The lowest VK are in the Kudrè-915 section: $92.9 \%$ for TOC and $37.5 \%$ for TIC. TOC is more vari- able in the Slavè-2 section (VK $=178 \%$ ) than in the Vindžiūnai-136 section (VK $=108 \%$ ), while the variation in TIC is higher in the Vindžiūnai-136 section ( $\mathrm{VK}=74.7 \%)$ compared to the Šlavè-2 section (VK = 46.1\%).

Estimation of the percentage of OM, total carbonates (TCR) and non-carbonate minerals (NCM), according to TOC and TIC values, revealed some differences between the sections. In almost all samples the NMC component prevails, its highest percentage being in the Vindžiūnai-136 section (91.1-99.6\%, median value - 96.9\%); it is lower in the Šlavè-2 section (48.7-99.2\%, median value - 97.6\%) and lowest in the Kudrè-915 section (20.2-88.9\%, median value -68.3\%). As regards variability in NMC, the sections are arranged in the oppo- 


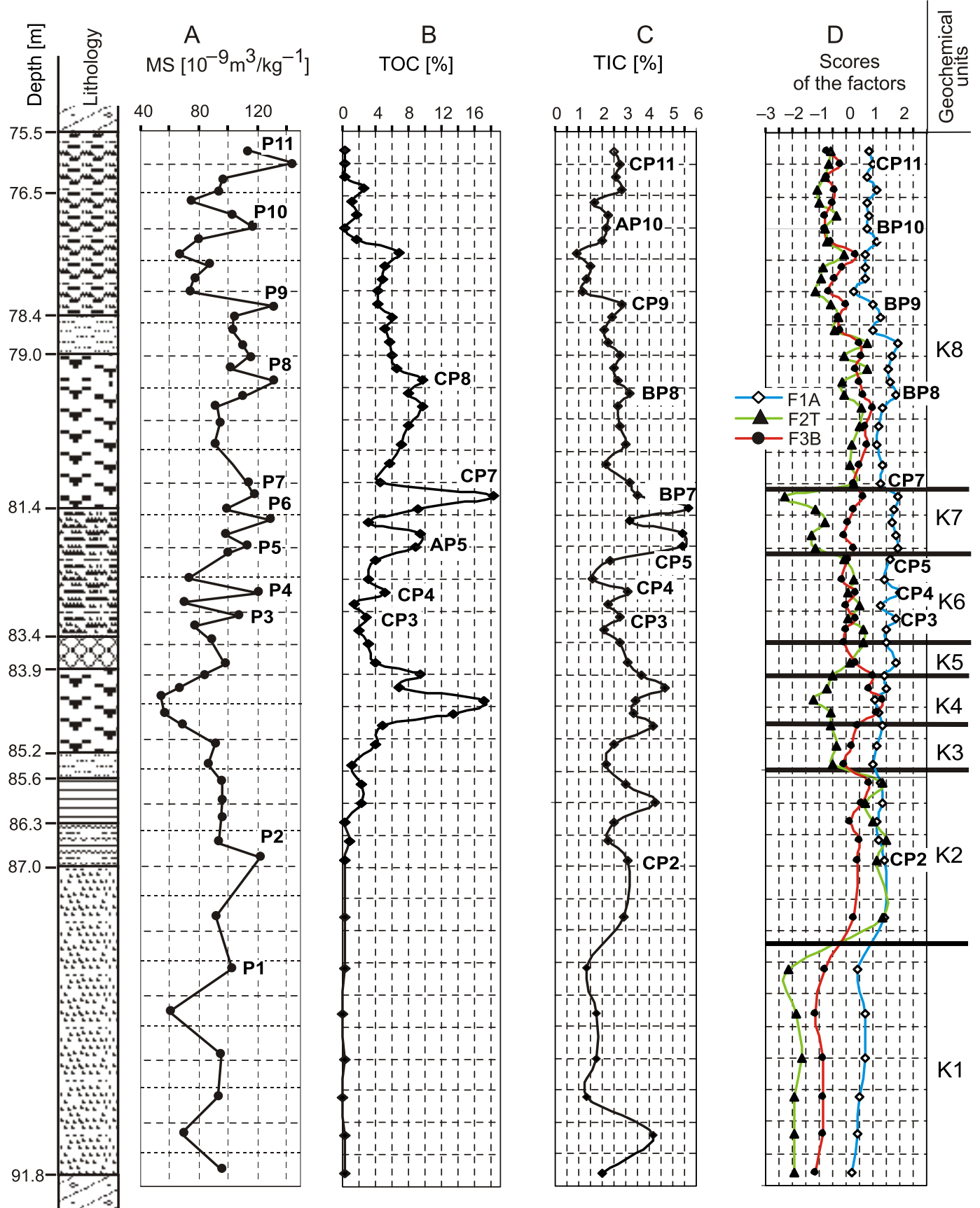

Fig. 13. Summary diagram of the Kudrè-915 borehole section

For explanations see Figures 4 and 11

site order (respective VK are 2.1\%, 13.8 and $26.1 \%$ ) as well as according to the percentage of OM: the lowest being in Vindžiūnai-136 $(0.11-6.47 \%$, median value $-0.69 \%)$, higher in Šlavè-2 (0.23-49.4\%, median value - 1.73\%) and highest in Kudrè-915 (0.30-50.8\%, median value $-10.9 \%)$. The arrangement of sections according to the percentage of total carbonates is a little different: the lowest is in Šlavè-2 $(0.08-1.94 \%$, median value $-0.93 \%)$, higher in Vindžiūnai-136 (0.24-6.43\%, median value - 1.63\%) and highest in Kudrè-915 (7.67-47.2\%, median value $-22.0 \%$ ).

\section{INVESTIGATION OF MAJOR} AND TRACE ELEMENTS

Factor analysis of the three sections combined enabled the distinction of three polar factors F1, F2, F3 having significant positive and significant negative loadings. Heathwaite and O'Sullivan (1991) reported that K and Al are characteristic of an allogenic component, whereas $\mathrm{Ca}$ and $\mathrm{Mn}$ reflect authigenic origin. According to Putschew et al. (1996) and Lückge et al. 
(2002), S can be taken as a typically biogenic element. Thus, $\mathrm{F} 1$ with significant positive loadings of $\mathrm{Ca}, \mathrm{P}, \mathrm{Mn}, \mathrm{Mg}, \mathrm{Br}, \mathrm{Fe}$ (also $\mathrm{Sr}, \mathrm{Zn}, \mathrm{Cu}$, and $\mathrm{K}$ ) and significant negative loadings of $\mathrm{Si}$, $\mathrm{Ti}, \mathrm{Zr}, \mathrm{Hf}, \mathrm{Al}$ (also Nb, Y, V, Ga, Cr, and Th) enables distinction between authigenic ( $\mathrm{Mn}$ and $\mathrm{Ca}$ have positive loadings) and allogenic (terrigenous) (Al has negative loading) materials. Most allogenic chemical elements ( $\mathrm{Al}, \mathrm{V}, \mathrm{Ti}, \mathrm{Cr})$, forming the significant negative loadings of this factor, were ascribed by Dean (2002) to an alumosilicate association. The fact that the most negative loadings are formed by $\mathrm{Si}, \mathrm{Zr}, \mathrm{Hf}, \mathrm{Ti}, \mathrm{Y}$, and $\mathrm{Nb}$, which are related to quartz and heavy minerals, suggests that this factor facilitates distinction between layers rich in authigenic minerals $(A)$ and layers rich in coarser terrigenous clastic material (Tc). Thus it would be more correct to mark it as F1(A-Tc), showing the opposition of these sediment types. Factor $\mathrm{F} 2$ with significant positive loadings of $\mathrm{Rb}, \mathrm{Ba}, \mathrm{Pb}$, Th, $\mathrm{Ga}, \mathrm{K}$, $\mathrm{Y}, \mathrm{Nb},(\mathrm{Ti}, \mathrm{Al}, \mathrm{Cr}, \mathrm{Hf}, \mathrm{Na}, \mathrm{Ni}, \mathrm{Sr}, \mathrm{Fe}, \mathrm{Zn}, \mathrm{V}, \mathrm{Zr}, \mathrm{Si})$ and significant negative loading of $\mathrm{Ca}$ facilitates distinction between finegrained terrigenous sediments (Tf) and $\mathrm{CaCO}_{3}$ sediments and can be marked as F2(Tf-A) because calcium carbonates usually are authigenic (A). Factor F3 with significant positive loadings of $\mathrm{Ni}, \mathrm{As}, \mathrm{S}, \mathrm{V}, \mathrm{Mo}, \mathrm{Cu}, \mathrm{Cr}$, Zn, (Th, Ga, Br, Pb, Fe, Y, and $\mathrm{Al}$ ) and significant negative loadings of $\mathrm{Na}, \mathrm{Sr}, \mathrm{Si}, \mathrm{Zr}$, and $\mathrm{Hf}$ is helpful in distinguishing between biogenic sediments (B) (characteristic element $S$ ) and terrigenous sediments $(T)$; it was marked as F3(B-T). Authigenic deposition is characteristic of intervals with higher $\mathrm{F} 1(\mathrm{~A}-\mathrm{Tc})$ scores, fine-grained terrigenous sedimentation of intervals with elevated F2(Tf-A) scores and biogenic sedimentation of intervals with elevated F3(B-T) values. According to the arrangement of factor scores, the three sections were divided into intervals of different deposition types. Thus 6 intervals were distinguished in Šlavè-2, 15 intervals in Vindžiūnai-136 and 8 intervals in the Kudrè-915 sections.

The sections differ in the dominant sedimentary origin: terrigenous or biogenic in Šlavè-2 (Fig. 11D) and in Vindžiūnai-136 (Fig. 12D) and authigenic in the Kudrè-915 (Fig. 13D). For investigation of interglacial deposits it is important to distinguish those intervals where the role of biogenic sedimentation is important or dominant. In the Šlavè-2 section (Fig. $11 \mathrm{D})$ it is dominant in the depth interval Š3 $(3.6-3.8 \mathrm{~m})$, showing a distinct peak, but also in Š2 (3.8-4.3 m), whereas within Š $(3.3-3.6 \mathrm{~m})$ and Š1 $(4.3-4.8 \mathrm{~m})$ its role is comparable with the role of terrigenous sedimentation. In the Vindžiūnai-136 section (Fig. 12D), biogenic sedimentation is dominant at a depth of 157.2-160.0 m (sedimentation intervals V1-V3), while there are intervals in this borehole where it is locally comparable with other modes of sedimentation: 157.2-157.8 $\mathrm{m}$ (V4) and 153.9-156.2 m (V6, V7, V8, V9). However, it is not as well expressed as in the Šlavè-2 section. In the Kudrè-915 section (Fig. 13D) biogenic sedimentation is significant not only in the interval 83.9-84.7 m (K4), where it is comparable with authigenic sedimentation, but also in the intervals 84.7-85.6 m (K3), $81.1-82.1 \mathrm{~m}(\mathrm{~K} 7)$ and part of $\mathrm{K} 8(75.5-81.1 \mathrm{~m})$ where it is subordinate to authigenic sedimentation.

Pairwise comparison of three sections using the MannWhitney U-test (significance level $p=0.05$ ) supports these findings. The Kudrè-915 section differs greatly from both other sections according to major elements: the contents of $\mathrm{Ca}, \mathrm{Mg}, \mathrm{Fe}$ and $\mathrm{P}$ are significantly higher and the contents of $\mathrm{Si}, \mathrm{Ti}, \mathrm{Al}$ are significantly lower, indicating the prevalence of authigenic sedimentation. Besides, in comparison with the Vindžiūnai-136 section, the Kudrè-915 section has a significantly higher content of $\mathrm{S}$ and significantly lower content of $\mathrm{Na}$. This section can be distinguished also according to trace elements: the contents of $\mathrm{Mn}, \mathrm{Br}$ and $\mathrm{Cu}$ are significantly higher than in the other two sections and the contents of Mo and As are significantly higher than in the Vindžiūnai-136 section. These patterns indicate that besides authigenic sedimentation, biogenic sedimentation also plays important role in this section.

The Šlavè- 2 and Vindžiūnai-136 sections, both of which are characterized by dominant terrigenous or biogenic sedimentation, are more similar according to contents of major and trace elements: according to the contents of $\mathrm{Si}, \mathrm{K}, \mathrm{Fe}, \mathrm{Zr}, \mathrm{Hf}, \mathrm{Ba}$ and $\mathrm{Br}$ there are no significant differences between them. The contents of most chemical elements (S, Mo, As, Cu, Zn, Ni, V, Y, Ti, $\mathrm{Nb}, \mathrm{Al}, \mathrm{Ga}, \mathrm{Cr}, \mathrm{Th}, \mathrm{Pb}, \mathrm{Rb}$ ) are significantly higher in the Šlavè-2 section than in Vindžiūnai-136, the first seven of these elements characterize biogenic sedimentation. The Šlavè-2 section has the highest peaks and variability of $\mathrm{S}, \mathrm{Mo}, \mathrm{As}, \mathrm{Cu}, \mathrm{Zn}, \mathrm{Ni}, \mathrm{V}, \mathrm{Y}$, $\mathrm{Zr}, \mathrm{Hf}, \mathrm{Ba}$. By contrast, the contents of $\mathrm{Ca}, \mathrm{Mg}, \mathrm{P}, \mathrm{Na}, \mathrm{Mn}, \mathrm{Sr}$ are significantly higher in the Vindžiūnai-136 section than in Šlavè-2. The Vindžiūnai-136 section is characterized by the highest contents and highest variability of $\mathrm{Fe}$ and $\mathrm{Mn}$.

\section{GENERALIZATION AND DISCUSSION}

According to previous pollen investigations, the Vindžiūnai-136 section represents the deposits of the oldest interglacial known in Lithuania (Kondratienè, 1996). Mixed coniferous-deciduous forests, with a high presence of Quercus are characteristic of this interglacial. The forests were not thick, with some woodless areas. This is shown by pollen of Larix, Rhododendron and Ephedra. A number of exotic and extinct species are found in the flora. According to Kondratienè (1996) the pollen composition identified from the Vindžiūnai-36 section is very similar to that of the Šlavè-2 section and presumably these two sections were contemporaneous. However, macrofossil studies could not support this inference as the plant macroremain flora identified differs in both sections. The flora assemblage of the Šlavè-2 section includes the largest number of extinct species and such Pliocene relict species as Salvinia apthosa Wieliczk., which is characteristic for the north and east European Early Pleistocene flora (Velichkevich and Zastawniak, 2006).

Stratigraphical correlation of the Vindžiūnai-136 macrofossil assemblage is possible with the Augustovian Interglacial in Poland (Stachowicz-Rybka, 2011). In Belarus, the Korchevian interglacial flora is most closely related, in terms of age, to the flora of the Vindžiūnai Interglacial (Velichkevich et al., 1998). Another possibility is of correlation of the Šlavè-2 section with the Augustovian Interglacial deposits in Poland and this may be supported by the presence of Pliocene plant macroremains. In this case the Vindžiūnai-136 section deposits correspond to the Domuratovian Interglacial, as the pollen spectra representing both sequences show some similarities (Lindner et al., 2004; Lindner and Marks, 2008).

More information has been accumulated as regards the deposits of the Turgeliai Interglacial. Mixed conifer and broadleaved forests with Corylus undergrowth are typical of this period. Broad-leaved taxa including hornbeam and hazel spread in the forest almost simultaneously, and conifers dominated. A marked spread of alder trees is typical of the first half of the interglacial, while a spread of fir trees appeared in the second half. Ilex, Buxus and Ligustrum then grew under favourable conditions (Kondratienè, 1996). The Kudrè-915 section, representing the Turgeliai Interglacial, correlates with the Ferdynandovian interglacial according to its pollen and diatom content (Marciniak and Lindner, 1994; Ber, 2005).

During the investigation of the Early Pleistocene strata in the Daumantai outcrops, the Brunhes/Matuyama boundary was 
established (Baltrūnas et al., 2013a). According to available palaeomagnetic data, the interglacial deposits of the Šlavè-2 outcrop can be attributed to the Matuyama Chron (Early Pleistocene). The zone of mixed magnetic polarity is distinguished in the lower part of the outcrop. As this zone occupies about $1.7 \mathrm{~m}$, it can only be regarded as the Jaramillo subchron. The doubts (due to a small number of samples) as to the Jaramillo subchron in the Daumantai-3 outcrop (Baltrūnas et al., 2013a) were settled by the results obtained on the Šlavë-2 outcrop. The Brunhes/Matuyama palaeomagnetic boundary has been identified in some key interglacial sites in Poland, helping to interpret the results of many years of climatostratigraphic research (Lindner et al., 2013). Composite interglacials are characteristic of the interval MIS 22-12 and reflect a transition from a climate system dominated by $41 \mathrm{ka}$ orbital cycles to those dominated by 100 ka cycles. Based on these general differences, the MIS 23/22 and MIS 12/11 boundaries are recommended as key thresholds of the Pleistocene and may be reconsidered as the lower boundaries of Middle and Late Pleistocene, respectively (Lindner et al., 2013).

Therefore, the results of recent palaeomagnetic investigations suggest the formation of all three sections investigated during different interglacials.

This inference may be confirmed by geochemical data. Geochemical analysis revealed distinct differences between the sections. The concentration of $\mathrm{Ca}$ and TIC in Kudrè-915 is significantly higher than in the other two sections, indicating a much higher content of carbonates in this section. The obvious difference according to $\mathrm{CaCO}_{3}$ content may reflect a few factors:

1 - a higher concentration of carbonates in the glacial deposits of the Dzūkija Glacial preceding the Turgeliai Interglacial than in the glacial deposits formed during the Kalviai Glacial and in pre-Pleistocene sediments;

2 - different sedimentation conditions, i.e. a dominance of authigenic sedimentation during the Turgeliai Interglacial.

The presumption was made in this research that the second reason plays an important role and the climate is one of the most important among many factors determining the proportion of authigenic and allogenic fractions in the lake sediments. The investigation of carbonate lakes in the north-west of England has shown that during warm intervals there is increased lake productivity through marl precipitation and decreased delivery of detrital material (Nolan et al., 1999). Geiss et al. (2003) stated that during periods of forest growth within the watershed, deposition of terrigenous material is low and authigenic minerals prevail in sediments, while during dry periods deposition of terrigenous material increases due to increased dust deposition and the erosion of lake margins caused by lowered water levels.

These findings emphasize the importance of different inorganic components of lake sediments: total carbonates (TCR) and non-carbonate minerals (NCM), allogenic and authigenic fractions. We presumed that both proportions are important and tested two different means of estimation of the main components of lacustrine sediments: on the basis of TOC and TIC measurements and subsequent calculation of the percentage of OM, TCR and NCM (Geiss et al., 2003) and on the basis of the contents of major and trace elements with the help of factor analysis (Itkonen et al., 1999). Besides, using the second approach, estimation of the relative importance of allogenic, authigenic and biogenic fractions was possible.

The first method almost always yielded the highest percentage of non-carbonate minerals, while the second one showed different dominant sediments: terrigenous, authigenic and biogenic. The results of the second method show that in the Kudrè-915 section the authigenic sediments take first place, while the results of the first method indicate that the TCR component (presumably authigenic) is secondary to the NCM component. This may be because the NCM component distinguished by the first method does not necessarily include only allogenic (terrigenous) material, but may also include material rich in authigenic minerals other than $\mathrm{CaCO}_{3}$. Nevertherless a certain similarity between the two evaluations can be observed, because both an authigenic component and a TCR component (presumably authigenic) has a higher significance in the Kudrè-915 section than in the other two sections and an increase of median scores of the authigenic factor is observed in the same order as an increase of medians of the TCR component (Šlavè-2, Vindžiūnai-136, Kudrè-915), i.e. from older to younger deposits. Correlation between $\mathrm{Ca}$ and $\mathrm{TIC}$ is significant in all 3 sections, while between TIC and the authigenic factor it is significant only in the Kudrè-915 and Vindžiūnai-136 sections. The absence of significant correlation between TIC and the authigenic factor in the Šlavè-2 section indicates that carbonates are not dominant among authigenic minerals.

Analogous arrangement of sections from older to younger (Šlavè-2, Vindžiūnai-136, Kudrè-915) according to increase of medians of the TCR component and median scores of the authigenic factor might be influenced by different chemical compositions of the underlying strata. However, it might also be presumed that the Kudrè-915 section was formed in the warmest climatic conditions, Vindžiūnai-136 in cooler conditions and Šlavè-2 in the coolest climate. On the other hand, other reasons are also possible, e.g. according to Barešić et al. (2011), the distance from the shore of the lake is an important factor for determining the proportion of authigenic and allogenic fractions. So, increase in the authigenic fraction in the Kudrè-915 section might be due to a greater distance from the palaeolake shore.

Biogenic and authigenic components might be related as a result of combined sedimentation of authigenic minerals and autochthonous organic matter: it has been determined that when a lake is oligotrophic (low primary production), its sediments contain predominantly detrital minerals from the catchment and atmospheric dust; when it becomes mesotrophic, authigenic minerals are produced, especially during summer. However, the arrangement of sections according to increasing median percentage of OM (Vindžiūnai-136, Šlavè-2, Kudrè-915) is a little different from the arrangement according to increasing median percentage of TCR and median scores of the authigenic factor (Šlavè-2, Vindžiūnai-136, Kudrè-915) indicating a possible increase of allochthonous organic matter in the Šlavè-2 section. Despite the fact that TOC significantly correlates with the biogenic factor in all three sections, there is a difference between the arrangement of sections according to increasing median scores of the biogenic factor (Vindžiūnai-136, Kudrè-915, Šlavè-2) and their arrangement according to increasing median percentage of OM (Vindžiūnai-136, Šlavè-2, Kudrè-915). However, the common feature is that both indices are lowest in the Vindžiūnai-136 section. Besides, there are similarities between the intervals of obvious increase of $\mathrm{OM}$ and the relative magnitude of biogenic factor score in the sections: in all intervals of Šlavè- 2 with OM $>10 \%$ (Š3 - 3.6-3.8 m; part of Š4), the biogenic factor has the highest scores; in almost all intervals of Kudrè-915 with OM > $10 \%$ (K4 - 83.9-84.7 m; part of K3, K7, K8), the biogenic factor exceeds the terrigenous factor; in interval V6 
(155.6-156.2 m) of the Vindžiūnai-136 section including the maximum of OM $(6.47 \%)$, the biogenic factor scores are the highest or in second place. The intervals obtained by the second method are usually wider.

The relative importance of each type of sedimentation in each section can be estimated according to the descending order of median factor scores (MFS) of each factor: authigenic (MFSa), terrigenous (MFSt) and biogenic (MFSb). In the Šlavè-2 section the arrangement is MFSb $>$ MFSt $>$ MFSa, in Vindžiūnai-136 it is MFSt > MFSa > MFSb, and in Kudrè-915 it is MFSa > MFSb > MFSt. So, the main geochemical peculiarities of the Šlavè-2 section are determined by the proportion of biogenic and terrigenous components, in Vindžiūnai- 136 by the proportion of terrigenous and authigenic components, and in the Kudrè-915 section by the proportion of authigenic and biogenic components.

The proportion between authigenic and terrigenous fractions has been found to influence sediment magnetic properties (Nolan et al., 1999; Geiss et al., 2003). When investigating Holocene lake sediment records, Geiss et al. (2003) applied a bimodal mixing model that links authigenic and terrigenous magnetic minerals to palaeoenvironmental changes. They showed that when deposition of terrigenous material is low, sediment magnetic susceptibility is low and is related mainly to authigenic minerals, while elevated input of terrigenous material in dry periods usually causes its increase.

However, the results of this research conflict with the model of Geiss et al. (2003): median values of MS increase in the same order as median scores of the authigenic factor, i.e. from older to younger deposits: Šlavè-2 (Early Pleistocene), Vindžiūnai-136 (Vindžiūnai Interglacial), Kudrè-915 (Turgeliai Interglacial). The explanation could be that the model of Geiss et al. (2003) was applied only to Holocene deposits, while the palaeolake deposits researched here are of interglacial age. Therefore, the different chemical composition of deposits underlying the interglacial strata seems to have greater influence on MS than does the nature of sedimentation. For example, in the Daumantai-1 section MS values are lower than in the Šlavè-2, Vindžiūnai-136 and Kudrè-915 sections (in some intervals they are negative), this pattern may be explained by intense weathering and a high content of quartz (Baltrūnas et al., 2013a). The available data on the MS of the younger deposits of the Butenai Interglacial shows the amplitude of their magnetic susceptibility variability to be the largest. Based on this evidence, it can be presumed that the increase in MS was associated with the increase in magnetized particles in the younger interglacial lacustrine deposits whose terrigenous portion was generated by reworking of less weathered glacigenic material.

Other results from this research also contradict the model of Geiss et al. (2003): in the Šlavè-2 and Vindžiūnai-136 sections, MS has the highest significant Pearson correlation coefficient with the biogenic factor, while in the Kudrè-915 section it correlates with the authigenic factor, but not with the terrigenous factor. In the Šlavè-2 and Vindžiūnai-136 sections, MS significantly correlates not only with $\mathrm{Fe}$, but also with the specific elements $\mathrm{S}, \mathrm{Br}$ and $\mathrm{As}$ that are related to organic matter, while in Kudrè-915 it correlates with the specific authigenic elements $\mathrm{Mn}$ and $\mathrm{P}$.

Correspondence analysis of the main peaks of MS and other variables shows a lower influence of terrigenous factor on MS than expected.

In the Šlavè-2 section, most of the MS peaks (P3, P5-P9) correspond to peaks of TOC or of the biogenic factor, and some of them (P7, P8) also correspond to peaks of TIC (or TIC peaks are slightly above MS peaks P5, P6; Fig. 11). Correlation of MS with the authigenic factor is significant, while that with the terrigenous factor is insignificant.

Generally similar patterns are seen in the Vindžiūnai-136 section: MS peaks P1, P3, P7 correspond to peaks of biogenic factor or TOC, while MS peaks P2, P4, P5, P6 are close to these, and MS peaks P5, P6, P7 correspond to peaks of TIC, and other MS peaks are close to TIC peaks (Fig. 12). However, in the upper part of this section the influence of terrigenous material on MS is obvious (MS peaks P7, P8 correspond to peaks in the terrigenous factor; MS peaks $\mathrm{P} 6, \mathrm{P} 5$ are close to them). $\mathrm{A}$ lower correspondence of MS peaks and peaks of biogenic factor or TOC in the Vindžiūnai-136 section can be explained by very low contents of organic matter compared to other sections. Not only an authigenic, but also a terrigenic factor is significantly correlated with MS in this section.

Kudrè-915 is characterized by quite different patterns (Fig. 13): MS peaks P2, P3, P4, P5, P7, P9, P11 correspond to peaks of the authigenic factor or of TIC, and P6, P8, P10 are near to them. Besides, MS peaks P3, P4, P7, and P8 correspond to peaks of TOC and peak P5 is close to it. However, correlation of MS with the biogenic factor as well as with the terrigenous factor is insignificant.

In search of a possible explanation of disagreement with the model of Geiss et al. (2003) a close look at the factor loading matrix was made. It turned out that Fe (the minerals of which predetermine MS) has significant positive loadings on all factors: the highest (0.634) on authigenic, lower (0.384) on terrigenous and the lowest $(0.364)$ on the biogenic factor. This implies that Fe can be related to different sedimentation modes including a terrigenous one. The explanation of the MS relationship with the authigenic factor and TIC can be based on the multi-element composition ( $\mathrm{Ca}, \mathrm{P}, \mathrm{Mn}, \mathrm{Mg}, \mathrm{Br}, \mathrm{Fe}$ ) of the authigenic factor. The authigenic factor can therefore include not only weakly-magnetic $\mathrm{CaCO}_{3}$ which reduces $\mathrm{MS}$ values, but also other different authigenic minerals: Fe-Mn oxyhydroxides, phosphates (vivianite), siderite. Geiss et al. (2003) have found authigenic siderite in some horizons which may be characterized by high MS. It is quite possible that due to these other authigenic minerals, MS increases even more than due to terrigenous minerals.

Our research shows an increase of MS also in biogenic deposits, despite the well-known non-magnetic properties of organic matter and the statement of Geiss et al. (2003) that increase in OM leads to anoxic sediment conditions and reductive dissolution of iron oxides. However, authigenic mineral formation can be caused not only by abiotic, but also by biotic processes (Geiss et al., 2003). So, an increase in the biogenic factor and TOC can cause biotic processes of authigenic mineral formation, e.g. magnetotactic bacteria produce narrowly sized single-domain (SD) magnetite (Petersen et al., 1986). Moreover, MS depends also on the size of magnetic minerals, therefore terrigenic sediments which are usually coarse-grained have higher concentrations of magnetic minerals than organic matter or authigenic sediments which are usually fine-grained (Geiss et al., 2003). However, two statements by Geiss et al., (2003) are consistent with the explanation of our findings of MS relationship with the biogenic factor and TOC in the Šlavè-2 and Vindžiūnai-136 sections:

1 - an authigenic fine-grained (single-domain) component may occur throughout the entire record and may be detected only when terrigenous input into the lakes is low; 
2 - during reductive dissolution of iron oxides, initially, smaller particles are preferentially removed leading to a coarsening of the magnetic component (therefore an increase in MS);

3 - shallower and better oxygenated regions tend to be more magnetic than deep-water deposits.

So, increase of MS in these two sections might be explained mainly by shallow lake conditions and low input of terrigenic material, and also by probable coarsening of the magnetic component due to partial reductive dissolution of iron oxides. Besides, in the upper part of the Vindžiūnai-136 section the influence of the terrigenous component increases and it obviously overshadows the biogenic component (P7 peak of MS).

\section{CONCLUSIONS}

1. Based on palaeomagnetic data, the lacustrine sediments of the Šlavè-2 outcrop were slowly deposited by sediment derivation from the west during the Early Pleistocene and may be attributed to the palaeomagnetic Matuyama Chron. The lower part of the section is distinguished by a mixed polarity zone which belongs to the Jaramillo subchron. This enables correlation of the data obtained with the global palaeomagnetic column.

2. The increase of magnetic susceptibility (MS) in the interglacial lacustrine deposits is associated with an increase of the content of magnetized particles in these deposits, the terrigenous portion of which was deposited by reworking of glacigenic sediments. According to the elevation of MS it is possible to distinguish the interglacial deposits formed in an environment of glacigenic relief, i.e. in the territory of the first glacier covering East Lithuania.

3. Geochemical peculiarities of the Šlavè-2 section, attributed to the Early Pleistocene, are determined by the proportion of terrigenous and biogenic components. The highest median contents of $\mathrm{Ti}, \mathrm{Nb}, \mathrm{V}, \mathrm{Al}, \mathrm{Ga}, \mathrm{Cr}$, Th, Y, Pb, Rb compared to other sections and generally high median contents of $\mathrm{Si}, \mathrm{Zr}, \mathrm{Hf}$ and $\mathrm{Ba}$ indicate an influence of the terrigenous component, while the highest median contents of $\mathrm{S}$ and $\mathrm{Ni}$ and high median TOC value $(0.62 \%)$ indicate biogenic input. Biogenic sedimentation is especially pronounced in the S 3 unit $(3.6-3.8 \mathrm{~m})$, the biogenic factor prevails in the lower part of the section (from 4.8 to $3.6 \mathrm{~m}$; i.e. in $\mathrm{S} 1-\mathrm{S} 3$ units); and terrigenous sedimentation is dominant in the upper part (from 3.3 to $2.4 \mathrm{~m}$; i.e. in the Š5 and Š6 units).

4. Geochemical peculiarities of the Vindžiūnai-136 section, which represents the Vindžiūnai Interglacial, are determined by the proportion of terrigenous and authigenic components, the biogenic component being less important. The highest median contents of $\mathrm{Si}, \mathrm{Zr}, \mathrm{Hf}, \mathrm{Ba}, \mathrm{Na}$ and generally high median contents of $\mathrm{Ti}, \mathrm{Nb}, \mathrm{V}, \mathrm{Al}, \mathrm{Ga}, \mathrm{Cr}$, Th, Y, Pb, Rb compared to other sections confirm the influence of the terrigenous component, while the high median of $\mathrm{Ca}, \mathrm{Mn}, \mathrm{P}$ and of $\mathrm{TIC}(0.20 \%)$ and the highest median content of $\mathrm{Sr}$ indicate an authigenic input. The lowest median TOC value $(0.25 \%)$ indicates the small role of biogenic sedimentation, though this prevails in the lower part of the section (from 160 to $157.8 \mathrm{~m}$; i.e. in the V1-V3 units) and is also important in the middle part (from 156.2 to 153.9 m; i.e. in the V6-V9 units). However, in the interval 156.2-157.2 m of the middle part (i.e. in the V5 unit) and especially in the upper part of section (from 154 to $146 \mathrm{~m}$; i.e. in units V10-V15) terrigenous sedimentation clearly prevailed.

5. The Kudrè-915 section, which represents the Turgeliai Interglacial, differs greatly from the other two sections. The Kudrè palaeolake was dominated by authigenic sedimentation. Significantly higher contents of $\mathrm{Ca}, \mathrm{Mg}, \mathrm{Fe}, \mathrm{P}$ and TIC (2.64\%) and significantly lower contents of $\mathrm{Si}, \mathrm{Ti}, \mathrm{Al}$ by comparison with the other two sections, and high scores of the authigenic factor, support this inference. Geochemical peculiarities of this section are determined by the proportion of authigenic and biogenic components. The highest median TOC value (3.89\%) shows the influence of biogenic component, clearly observed in the interval 83.9-84.7 m (K4 unit).

6. The palaeoflora assemblages in the deposits studied show that the Turgeliai Interglacial was warmer than the Vindžiūnai Interglacial. The older age of Vindžiūnai Interglacial is shown by abundance of fossil Pliocene species (Pilularia pliocenica Dorof., Typha ex gr. pliocenica Dorof., Ranunculus sceleratoides Nikit., Hypericum cf. tertiaerum Nikit.) and by species which were present in northern and eastern Europe only in the Early Pleistocene: Salvinia aphtosa Wieliczk., Selaginella tetraedra Wieliczk., Potamogeton perforatus Wieliczk. and Myriophyllum subspicatum Wieliczk. These first Middle Pleistocene interglacials can be attributed to the coolest ones marked by weaker biogenic sedimentation.

Acknowledgements. The authors are grateful to the Research Council of Lithuania for their financial support of the project "Ciklas" (reg. No LEK-12007, agreement No LEK-06/2012). The authors appreciate very much the work of the three anonymous reviewers and of the editor W. Granoszewski, who made critical and constructive comments on the manuscript. We are grateful to J. Zalasiewicz who checked the English language.

\section{REFERENCES}

Baltrūnas V. (2002) Stratigraphical subdivision and correlation of Pleistocene deposits in Lithuania (methodical problems). Institute of Geology, Vilnius.

Baltrūnas V., Karmaza B., Pukelytè V. (2008) Multilayered structure of the Dzūkija and Dainava tills and their correlation in South Lithuania. Geological Quarterly, 52 (1): 91-99.

Baltrūnas V., Zinkutė R., Šeirienè V., Katinas V., Karmaza B., Kisielienè D., Taraškevičius R., Lagunavičienè L. (2013a) Sedimentary environment changes during the Early-Middle
Pleistocene transition as recorded by the Daumantai sections in Lithuania. Geological Quarterly, 57 (1): 45-60.

Baltrūnas V., Šeirienè V., Molodkov A., Zinkutè R., Katinas V., Karmaza B., Kisielienè D., Petrošius R., Taraškevičius R., Piličiauskas G., Shmolcke U., Heinrich D. (2013b) Depositional environment and climate changes during the late Pleistocene, as recorded by the Netiesos section in South Lithuania. Quaternary International, 292: 136-149. 
Barešić J., Horvatinćić N., Vreča P., Sironić A. (2011) Distribution of authigenic and allogenic fractions in recent lake sediment: isotopic and chemical compositions. Acta Carsologica, 40: 293-305.

Battarbee R.W. (1986) Diatom analysis. In: Handbook of Holocene Palaeocology and Palaeohydrology (ed. B.E. Berglund): 527-570. John Wiley and Sons, Chichester.

Ber A. (2000) Pleistocene of north-eastern Poland and neighbouring areas against crystalline and sedimentary basement (in Polish with English summary). Prace Państwowego Instytutu Geologicznego, 170.

Ber A. (2005) Polish Pleistocene stratigraphy - a review of interglacial stratotypes. Netherlands Journal of Geosciences-Geologie en Mijnbow, 84: 61-76.

Ber A. (2006) Pleistocene interglacials and glaciations of northeastern Poland compared to neighbouring areas (in Polish with English summary). Quaternary International, 149: 12-23.

Ber A., Lindner L., Marks L. (2007) Proposal of a stratigraphic subdivision of the Quaternary of Poland (in Polish with English summary). Przegląd Geologiczny, 55: 115-118.

Berggen G. (1969) Atlas of seeds and small fruits of Northwest-European plant species with morphological descriptions, Part 2 , Cyperaceae. Berlingska Boktryckeriet, Lund.

Berggen G. (1981) Atlas of seeds and small fruits of Northwest-European plant species with morphological descriptions, Part 3, Salicaceae-Cruciferae. Berlings, Arlöv.

Boyle J.F. (2001) Inorganic geochemical methods in palaeolimnology. In: Tracking Environmental Change Using Lake Sediments (eds. W.M. Last and J.P Smol). Volume 2: Physical and Geochemical Methods. Kluwer Academic Publishers, Dordrecht.

Cañón-Tapia E. (2004) Anisotropy of magnetic susceptibility of lava flows and dykes: a historical account. Geological Society Special Publications, 238: 205-225.

Cappers R.T.J., Bekker R.M., Jans J.E.A. (2006) Digital seed atlas of the Netherlands. Groningen. Barkhius Publishing and Groningen University Library.

Cohen K.M., Gibbard P.L. (2011) Global chronostratigraphica correlation table for the last 2.7 million years. University of Cambridge, Utrecht University, INQUA, http://www.nhm2.uio.no/norges/GTS2012_Quaternary-Poster-GSA2012.pdf

Dean W. (2002) A 1500-year record of climatic and environmental change in Elk Lake, Clearwater County, Minnesota II: geochemistry, mineralogy, and stable isotopes. Journal of Paleolimnology, 27: 301-319.

Dean W.E., Schwalb A. (2000) Holocene environmental and climatic change in the Northern Great plains as recorded in the geochemistry of sediments in Pickerel Lake, South Dakota. Quaternary International, 67: 5-20.

Engstrom D.R., Wright H.E. (1984) Chemical stratigraphy of lake sediments as a record of environmental change. In: Lake Sediments and Environmental History (eds. E.Y. Haworth and J.W.G. Lund): 11-69. Leicester University Press, Leicester, UK.

Erdtman G. (1936) New method in pollen analysis. Svensk Botanisk Tidskrift, 30: 154-164.

Gaigalas A.I. (1987) Neogene-Quaternary boundary in Baltic region (in Russian with English summary). In: The Boundary Between the Neogene and Quaternary systems on the USSR (eds. M.N. Alekseev and K.V. Nikiforova): 13-26. Nauka, Moscow.

Gaigalas A. (1995) Glacial history of Lithuania. In: Glacial Deposits in North-East Europe (eds. J. Ehlers, S. Kozarski and Ph. Gibbard): 127-135. A.A. Balkema, Rotterdam.

Gaigalas A. (2008) Quaternary research in the Baltic countries. In: History of Geomorphology and Quaternary Geology. Geological Society of London: 129-140.

Garunkštis A. (1975) Sedimentary processes in lakes of Lithuania (in Russian). Mokslas, Vilnius.
Geiss C.E., Umbanhowar C.E., Camill P., Banerjee S.K. (2003) Sediment magnetic properties reveal Holocene climate change along the Minnesota prairie-forest ecotone. Journal of Paleolimnology, 30: 151-166.

Grichiuk A.I. (1940) The preparation methodology of the organic poor sediments for the pollen analysis. Problems of physical geography (in Russian). Nauka, Moscow.

Grigas A. (1986) Fruits and seeds of Lithuanian plants (in Russian). Vilnius: Mokslas, Vilnius.

Gudžinskas Z. (1999) Vascular Plants of Lithuania (in Russian). Vilnius: Institute of Botany.

Guobytė R., Satkūnas J. (2011) Pleistocene Glaciations in Lithuania. Developments in Quaternary Science, 15: 231-246.

Heathwaite A.L., O'Sullivan P.E. (1991) Sequential inorganic chemical analysis of a core from Slapton Ley, Devon, UK. In: Environmental History and Palaeolimnology (eds. J.P. Smith, P.G. Appleby, R.W. Battarbee, J.A. Dearing, R. Flower, E.Y. Haworth, F. Oldfield and P.E. O'Sullivan). Kluwer Academic Publishers. Printed in Belgium.

Iberla K. (1980) Factor analysis (in Russian). Statistika, Moskva.

Itkonen A., Marttila V., Meriläinen J.J., Salonen V.-P. (1999) 8000-year history of palaeoproductivity in a large boreal lake. Journal of Paleolimnology, 21: 271-294.

Jelinek V. (1977) The statistical theory of measuring anisotropy of magnetic susceptibility of rocks and its application, Geofyzika, s.p., Brno.

Kirschvink J. (1980) The least squares line and plane and the analysis of paleomagnetic data. Geophysical Journal of the Royal Astronomical Society, 62: 699-718.

Kondratienè O. (1996) The Quaternary stratigraphy and paleogeography of Lithuania based on paleobotanic studies (in Russian with English summary). Academia, Vilnius.

Kondratienė O., Riškienè M. (1971) Palaobotanisch wurden die Ablagerungen des Unterpleistozans untersucht (in Russian with German summary). In: Aufbau, lithologie und stratigraphie der Ablagerungen des Unterpleistozäns in Litauen (eds. P. Vaitiekūnas and O. Kondratienè): 57-115. Mintis, Vilnius.

Leong L.S., Tanner P.A. (1999) Comparison of methods for determination of organic carbon in marine sediment. Marine Pollution Bulletin, 38: 875-879.

Lindner L., Marks L. (2008). Pleistocene stratigraphy of Poland and its correlation with stratotype sections in the Volhynian Upland (Ukraine). Geochronometria, 31: 31-37.

Lindner L., Gozhik P., Marciniak B., Marks L., Yelovicheva Y. (2004) Main climatic changes in the Quaternary of Poland, Belarus and Ukraine. Geological Quarterly, 48 (2): 97-114.

Lindner L., Marks L., Nita M. (2013) Climatostratigraphy of interglacials in Poland: Middle and Upper Pleistocene lower boundaries from Polish perspective. Quaternary International, 292: $113-123$

Lückge A., Horsfield B., Littke R., Scheeder G. (2002) Organic matter preservation and sulfur uptake in sediments from the continental margin off Pakistan. Organic Geochemistry, 33: 477-488.

Marciniak B., Lindner L. (1994) Diatoms and geology of the Ferdynandovian interglacial lake sediments in Poland (in Polish). Polish Botanical Studies. Guidebook Series.

Miller U., Florin M.-B. (1989) Diatom analysis. Introduction to methods and applications. PACT, 24: 133-157.

Nolan S.R., Bloemendal J., Boyle J.F., Jones R.T., Oldfield F., Whitney M. (1999) Mineral magnetic and geochemical records of late Glacial climatic change from two northwest European carbonate lakes. Journal of Paleolimnology, 22: 97-107.

O'Sullivan P., Reynolds C.S., eds. (2003) The Lakes Handbook: Limnology and Limnetic Ecology, Volume 1. Wiley-Blackwell. 
Petersen N., Dobeneck T. von, Vali H. (1986) Fossil bacterial magnetite in deep-sea sediments from the South Atlantic Ocean. Nature, 320: 611-615.

Putschew A., Scholz-Böttcher B.M., Rullkötter J. (1996) Early diagenesis of organic matter and related sulphur incorporation in surface sediments of meromictic Lake Cadagno in the Swiss Alps. Organic Geochemistry, 25: 379-390.

Satkūnas J., Grigienè A., Bitinas A. (2007) Stratigraphic division of the Lithuanian Quaternary: the present state (in Lithuanian with English summary). Geologijos akiračiai, 1: 38-46.

Schnurrenberger D., Russell J., Kelts K. (2003) Classification of lacustrine sediments based on sedimentary components. Journal of Paleolimnology, 29: 141-154.

Stachowicz-Rybka R. (2011) Flora and vegetation changes on the basis of plant macroremains analysis from an early Pleistocene lake of the Augustów Plain, NE Poland. Acta Palaeobotanica, 51: 39-103.

Šliaupa A. (2004) Prekvartero uolienu paviršius. In: Lietuvos Žemès gelmiu raida ir ištekliai (ed. V. Baltrūnas): 254-258. Petro ofsetas, Vilnius.

Velichkevich F.Yu., Zastawniak E. (2006) Atlas of the Pleistocene vascular plant macrofossils of the Central and Eastern Europe. W. Szafer institute of Botany, Polish Academy of Sciences, Kraków.

Velichkevich F.Yu., Kondratienè O., Kisielienè D. (1998) The new data on Early Pleistocene paleocarpological complexes in Lithuania. Geologija, 25: 92-101. 